\title{
AVALIAÇÃO DAS CARACTERISTICAS DE CHUVAS SIMULADAS MÉTODO FOTOGRÁFICO
}

\author{
IEDE DE BRITO CHAVES
}

Orientador: Prof. Dr. OCTAVIO FREIRE

Tese apresentada à Escola Superior de Agricultura "Luiz de Queiroz", da Universidade de São Paulo, para a obtenção do título de Doutor em Agronomia. Área de concentração: Solos $\theta$ Nutrição de Plantas.

PIRACICABA

Estado de São Paulo - Brasil

Março / 1985 
i i.

A minha querida esposa.

LUCIA HELENA

$$
\begin{aligned}
& \text { pelo estímulo, sugestões } \\
& \text { e colaboração. }
\end{aligned}
$$

AOs meus filhos IANA e ANDRE

DEDICO. 


\section{AGRADECIMENTOS}

- Ao Prof. Octávio Freire, pela orientação, estímu1o e amizade;

- Ao Prof. Antonio Francisco Iemma, pela orientação nos temas estatisticos;

- Ao caro colega e amigo Ivandro de França da Silva, meu mui procuxador e substituo no Departamento de Solos e Engenharia Rural do CCA-UFPB;

- Ao Prof. Renato Sarruge, pela colaboração na resolução dos problemas eletro-eletrônicos;

- Aos Profs. Antonio Francisco Sanches, Luiz Gera1do Mialhe e Marcos Milan, pela colaboração e o acesso às dependências do Departamento de Engenharia Rural da ESALQ;

- Ao Prof. Zilmar Ziller Marcos, pelo empéestimo da tela para anālise dos diapositivos;

- Ao Sr. Sebastião Willian Zebertto, pelo apoio téc nico fotográfico de inestimável valor;

- Aos Srs. Herculano Perecin, Luiz Afonso da Costa, Antônio Ruiz, Laudelino Polizel, Hélio Toledo Gomes, funcioná rios do Departamento de Engenharia Rural da ESALQ, pela colaboração indispensável e amizade;

- Ao Instituto Agronômico do Estado de São Paulo,na pessoa do Dr. Francisco Lombardi Neto, pelo empréstimo dos bi cos aspersores e subsídios técnicos; 
- A TECNAL - Equipamentos de Laboratório Ltda., pelo empréstimo do frequencímetro eletrônico;

- Ao Centro de Ciências Agrárias da Universidade Federal da Paraíba, pela oportunidade oferecida para realização deste Curso;

- A Comissão de Aperfeiçoamento do Pessoal do Ensino Superior (CAPES) do Ministério da Educação e Cultura, pela con cessão da bolsa de estudo;

- Ao Conselho Nacional de Desenvolvimento Cientifico e Tecnológico (CNPq) pelo auxilio financeiro parcial para exe cução da pesquisa; 


\section{INDICE}

Pägina

RE S UMO

$x$

SUMMARY $\ldots \ldots \ldots \ldots \ldots \ldots \ldots \ldots \ldots \ldots \ldots \ldots \ldots \ldots \ldots \ldots \ldots \ldots \ldots$

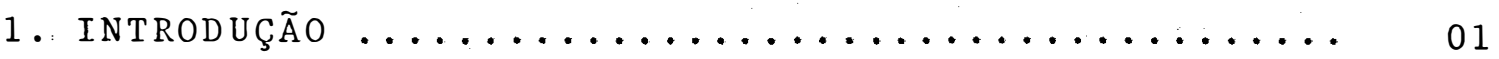

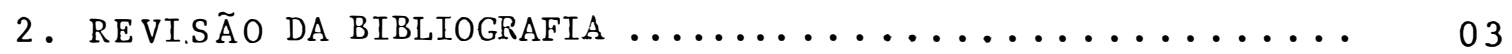

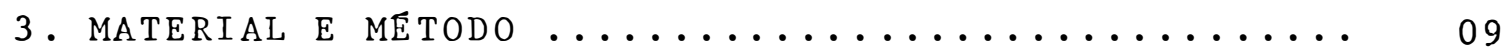

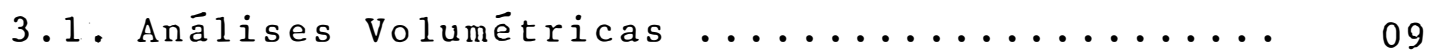

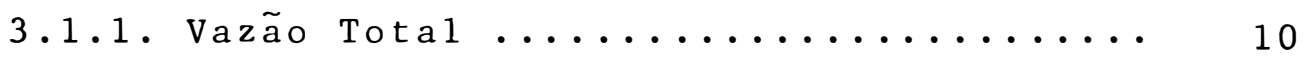

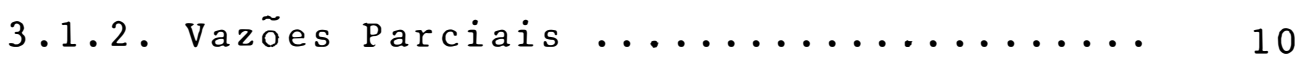

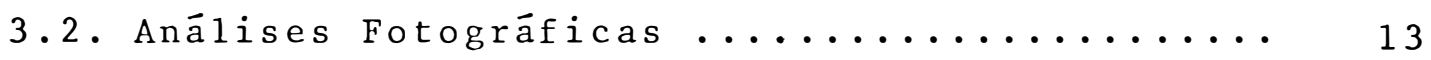

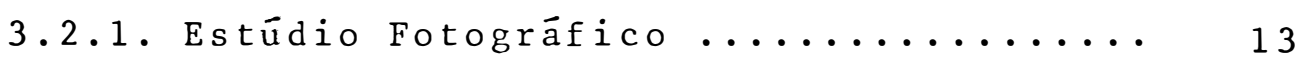

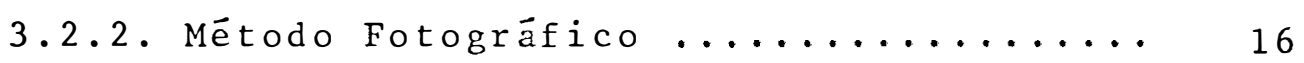

3.2.3. Avaliação do Método Fotográfico ........ 18

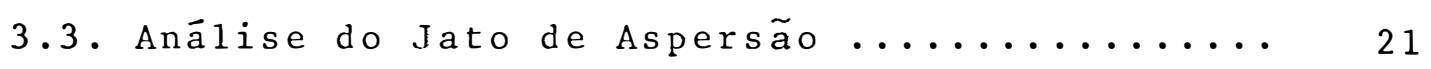

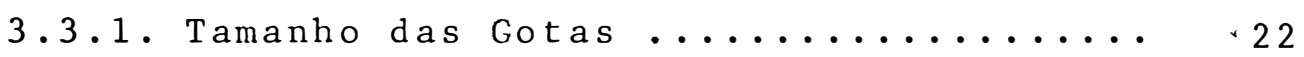

3.3.2. Velocidade das Gotas ............... 24

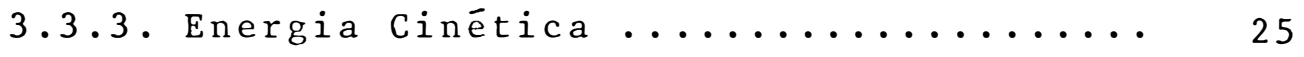

3.4. Características do simulador-de-chuva .......... 26

3.5. Cálculo da erosividade da chuva simulada .... 27

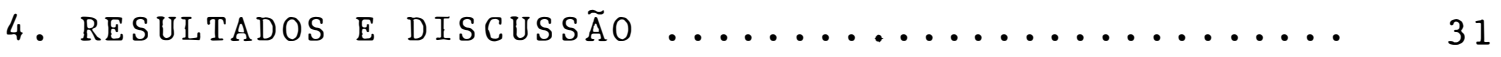

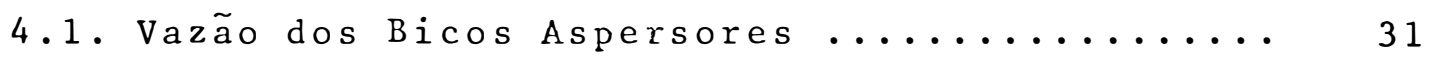

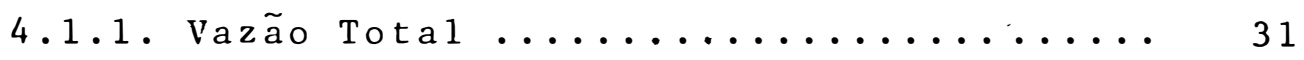

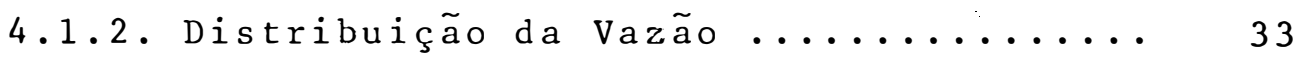

4.2. Avaliação do Método Fotográfico .......... 35 
4.2.1. Causas de erro nas leituras ........ 38

4.2.2. Medidas dos Diâmetros das Gotas ..... 39

4.2.3. Medidas das Velocidades de Queda ..... 42

4.3. Anālise do Jato de Aspersão .............. 44

4.3.1. Tamanho das Gotas ............. 45

4.3.2. Velocidade das Gotas ........... 47

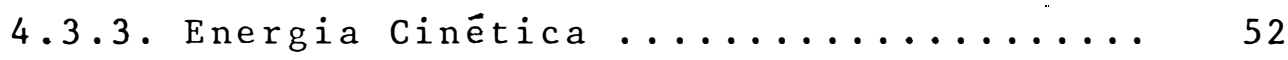

4.4. Características da Chuva Simulada ......... 54

4.4.1. Intensidade da Chuva ............. 58

4.4.2. Energia Cinética ................. 59

4.5. Erosividade da Chuva Simulada ........... 60

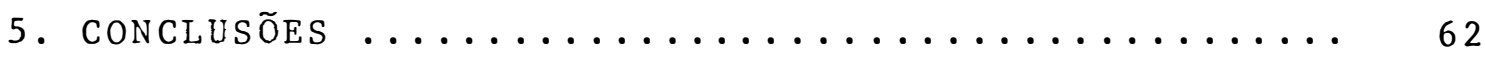

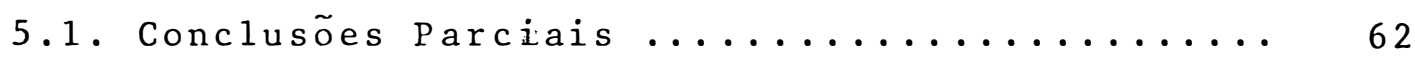

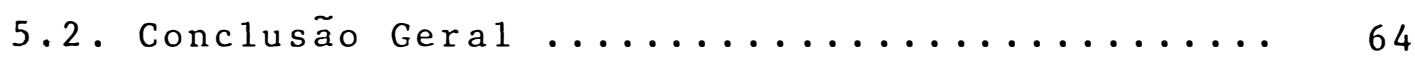

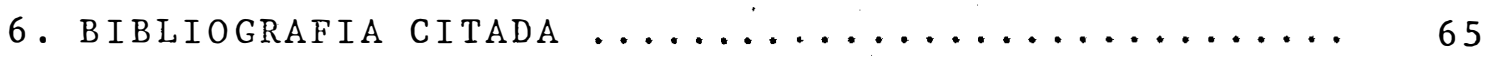

ANEXo: Sugestões para Pesquisa ............. 70 
vii.

\section{LISTA DE FIGURAS}

Pàgina

FIGURA 1. Estrado com funis coletores utilizados na avaliação da distribuição da vazão dos bi-

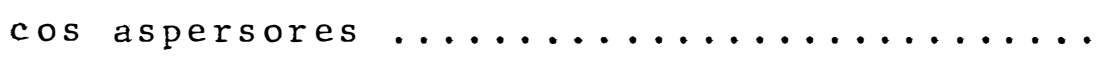

FIGURA 2. Planta baixa do estúdio fotográfico ......

FIGURA 3. (a) Gotas de diferentes diâmetros dos ensaios com chuva simulada (b) Gotas d'āgua de 5,2 mm de diâmetro e gotas filhas, ou sa télites, dos ensaios para a calibração do

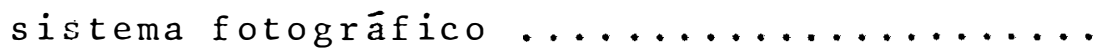

FICURA 4. Distribuição dos bicos aspersores no simulador -de-chuva, parcelas experimentais e alturas de aplicação da chuva simulada, para declividade de $9 \% \ldots$

FIGURA 5. Distribuição da vazão de bicos aspersores Veejet 80100 nacionais e americanos para uma pressão de $0,42 \mathrm{Kgf} . \mathrm{cm}^{-2} \ldots \ldots \ldots \ldots \ldots$

FIGURA 6. Gráfico de controle de qualidade dos aspersores nacionais para um intervalo de confiança com

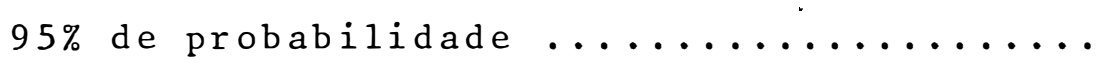

FIGURA 7. Velocidades de gotas d'água para diferentes alturas de queda, comparadas com as determi

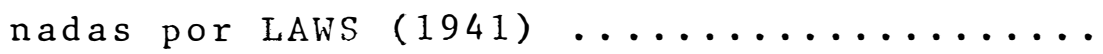


viii.

página

FIGURA 8. Velocidades de gotas da chuva simulada para diferentes alturas de queda e seções do jato de aspersão, comparadas com as velocidades terminais de gotas d'āgua determinadas por LAWS $(1941) \ldots \ldots \ldots \ldots \ldots \ldots \ldots \ldots \ldots \ldots \ldots \ldots \ldots \ldots \ldots \ldots . \ldots \ldots$

FIGURA 9. Distribuição das intensidades e das énergias cinéticas correspondentes, para chuva com 60 min de duração, produzida por bicos Veejet 80100 nacionais em simuladores-de chuva tipo rotativo, àpressão de $0,42 \mathrm{Kgf.cm}^{-2}$, 2 m de altura de queda e 30 bicos em funcio

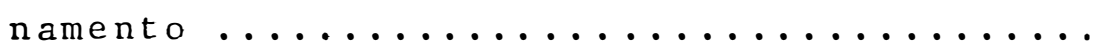

FIGURA 10. Distribuição das intensidades e das ener-gias cinéticas correspondentes, para chuva com 60 min de duração, produzida por bicos Veejet 80100 nacionais em simuladores-de-

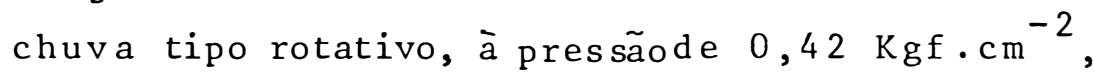
$3 \mathrm{~m}$ de altura de queda e 30 bicos em funcio

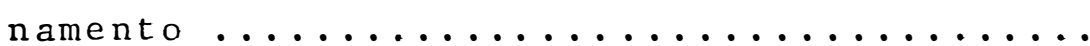

FICURA 11. Distribuição das intensidades e das energias cinéticas correspondentes, para chuva com 60 min de duração, produzida por bicos Veejet 80100 nacionais em simuladores -dechuva tipo rotativo, à pressão de $0,42 \mathrm{Kgf.cm}^{-2}$, $4 \mathrm{~m}$ de altura de queda e 30 bicos em funcio

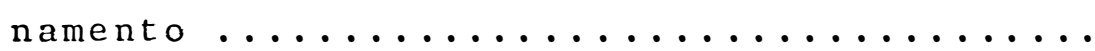




\section{LISTA DE TABELAS}

Pägina

TABELA 1. Valores médios de vazões de seções do jato de aspersão e vazão total de 10 bicos asper sores, a pressão de $0,42 \mathrm{Kgf} \mathrm{cm}^{-2}$ (6 Psi)..

TABELA 2. Relação entre diâmetro medido na fotografia e diâmetro esférico, de gotas d'ägua, para

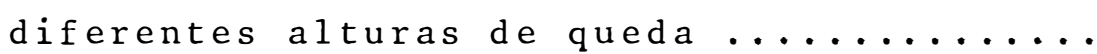

TABELA 3. Distribuição dos tamanhos das gotas em dife rentes alturas de queda e seções do leque de

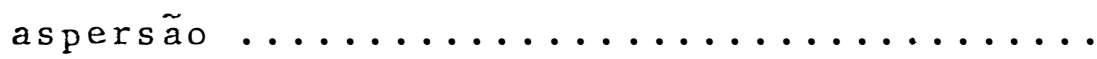

TABELA 4. Velocidades de gotas em diferentes alturas de queda e seções do leque de aspersão....

TABELA 5. Energia cinética em diferentes alturas de queda e seções do leque de aspersão ....... 


\title{
AVALIAÇÃO DAS CARACTERISTICAS DE CHUVAS SIMULADAS Método Fotográfico
}

\author{
Candidato: IÊDE DE BRITO CHAVES \\ Orientador: Prof. Dr. OCTAVIO FREIRE
}

RESUMO

o objetivo deste trabalho foi fazer uma anāIise do desempenho dos aspersores Veejet 80.100 de fabricação nacio nal e propor equações para o cálculo da energia cinética das chuvas simuladas, considerando-se as prováveis variações das características das gotas que caem. de diferentes alturas, em consequência da declividade da superfície do solo em que são aplicadas

Foram utilizados 10 aspersores para as anālises volumétricas e 6 para as anālises fotográficas, os quais foram mantidos funcionando à pressão de $0,42 \mathrm{kgf.cm}^{-2}$ (6Psi). A vazão total foi medida diretamente na saída do aspersor e a sua distribuição em 9 pontos equidistantes ao longo do leque de aspersão e com $2,4 \mathrm{~m}$ de altura de queda. As gotas foram fotografadas em cinco pontos ao longo do leque de aspersão e com três alturas de queda $(2,3$ e $4 \mathrm{~m})$.

Da discussão dos resultados obtidos chegou-se às seguintes conclusões: a) os bicos aspersores nacionais têm 
vazões variāveis e em mēdia, 8,1 I.min ${ }^{-1}$ a mais do que a dos bicos aspersores americanos; b) à pressão de 0,42 Kgf.cm ${ }^{-2}$ (6 Psi), os bicos nacionais, no simulador rotativo, produzem chuvas com intensidades de 94 e $188 \mathrm{~mm} \cdot \mathrm{h}^{-1}$, para 15 e 30 bicos em funcionamento; c) a energia cinética da chuva, produzi da por simuladores do tipo rotativo com bicos aspersores Veejet 80.100 nacionais, apresenta variações em sua distribuição que se modificam com a altura de queda, devido a diferen ças nostamanhos das gotas, velocidades de queda e intensidade; entretanto, o valor médio da energia cinética não variou para às alturas de aplicação das chuvas analisadas. 


\title{
EVALUATION OF THE SIMULATE RAINFALL CHARACTERISTICS \\ Photographic Method
}

\author{
Candidate: IEDE DE BRITO CHAVES \\ Adviser: Prof. Dr. OCTAVIO FREITE
}

\section{SUMMARY}

In this paper nozzles Veejet 80.100 manufactured in Brazil were utilized to study the flow rate as well as to establish equations to figure the kinetic energy for simulated rainfall considering the variability of the drops that fall from several heights, due to the degree of changes of the slope.

$$
\text { of the ten nozzles, all of them were used for }
$$

volumetric analyses and only six nozzles for photographic analyses at a pressure of $0.42 \mathrm{Kgf}_{\mathrm{cm}} \mathrm{cm}^{-2}$ (6Psi). The total flow was directly measured in the spray nozzle outlet, and the distribution at nine equidistant points along the spray, the height of the nozzles being maintained at 2.4 meters. The size and velocity of the water drops were photographed at five points along the spray and at three heights, namely, two, three, and four meters respective1y.

The results showed: a) there was variations in the flow rate with the nozzles utilized, with an average of 8.1 1iters/minute more than nozzles manufactured in the United States, 
xiii.

b) at the pressure $0.42 \mathrm{Kgf} \cdot \mathrm{cm}^{-2}$ ( $6 \mathrm{Psi}$ ), the nozzles utilized in rotating-boom rainfall simulator produced rainfall intensity of 94 and $188 \mathrm{~mm} \cdot \mathrm{h}^{-1}$, for 15 and 30 nozzles respectively, c) the kinetic energy of the rainfall produced by the rainfall simulator with nozzles Veejet 80100 manufactured in Brazil, presented variations in the distribution at different heights due to the differences in the size of drops, velocity of fall and intensity. The kinetic energy average value did not change with the height of the rainfall application. 


\section{INTRODUÇÃO}

A utilização de chuvas simuladas, em experimeñ tos de manejo de culturas e de conservação do solo e da água, passou a ser comum, em todo o Brasil, a partir do 19 Encontro Nacional de Pesquisa com o Uso de Simuladores-de-Chuva, reali zado em Londrina (Paranā), em 1975 .

o equipamento, que atualmente diversas instituições possuem, é do tipo rotativo, idealizado por swanson ( SWANS•N, 1965), de fabricação nacional.

Apesar das inúmeras vantagens oferecidas por esse aparelho, algumas limitações do modelo não permitem uma perfeita simulação das características da chuva natural. Essas limitações devem, portanto, ser bem conhecidas para que interpretações consistentes dos resultados possam ser obtidas. Além disso, nenhum controle de qualidade dos bicos asper sores está sendo feito: devendo ocorrer variação nas características da chuva simulada produzida pelos simuladores-de-chu va de fabricação nacional. 
Para a avaliação da erosividade da chuva simulada, o método que se apresenta como um dos mais satisfatórios, è o fotográfico, tendo, por essa razão, sido escolhido para este trabalho.

Utilizando o método fotográfico e avaliaçõesvo lumētricas, este trabalho pretende alcançar os seguintes objetivos:

a) determinar a vazão e sua distribuição, assim como a variabilidade dos bicos aspersores "Veejet 80.100" de fabricação nacional;

b) determinar a distribuição do tamanho e da velocidade das gotas em diferentes alturas de queda e em diferentes pontos ao longo do jato de aspersão;

c) propor uma expressão adequada para o cálculo da energia cí nética das chuvas simuladas, considerando-se as provāveis variações das características das gotas que caem de diferentes alturas, em consequência da declividade da superfície do solo em que são aplicadas.

Mesmo atendendo a todos esses aspectos do cálculo da erosividade das chuvas simuladas, não se pretende apre sentar uma solução cabal e definitiva do problema; mas, apenas uma metodologia que possa ser empregada para a determinação do tamanho e da velocidade das gotas de chuva. 


\section{REVISÃO DA BIBLIOGRAFIA}

Com as informações sobre velocidade de queda de diferentes tamanhos de gotas d'água, obtidos por LAWS (1941) e GUNN \& KINZER (1949) e com as informações sobre a distribuição do tamanho das gotas com a intensidade da chuva natural, obtidas por LAWS e PARSONS (1943), uma nova etapa foi iniciada no desenvolvimento dos simuladores-de-chuva. Bicos aspersores com uma distribuição de tamanho de gotas mais adequada, utilização da água sob pressão e direcionada para o solo, permitiu a aplicação de chuvas simuladas de alturas bem menores do que a dos antigos simuladores e com uma energia de impacto próxima à da chuva natural.

MEYER (1958), analisando diversos tipos de bicos aspersores, selecionou o Veejet 80.100 , como sendo o melhor para ser utilizado em simuladores-de-chuva. Este aspersor apresenta uma distribuição d'ägua em forma de leque e fun ciona a baixa pressão, produzindo uma alta vazão e uma boa distribuição de tamanho de gotas. 
Utilizando esses bicos aspersores MEYER e McCUNE (1958) desenvolveram o "Rainulator", um simulador considerado adequado para trabalhos em campo. Aplicando-se uma pre cipitação de $63,5 \mathrm{~mm} \cdot \mathrm{h}^{-1}$, esse equipamento produz $76 \%$ da energia cinética de uma chuva natural da mesma intensidade. Simulando chuvas naturais e suas variações de intensidade e comparando-as com suas respectivas perdas por erosão, BARNETT \& DOOLEY (1972) e YOUNG \& BURWELL (1972) encontraram uma alta correl ação.

Com características de chuva semelhantes às do "Rainulator", SWANSON (1965) desenvolveu um simulador de braços rotativos, montado sobre um chassis com quatro rodas, de fäcil transporte e maior simplicidade de operação. Este equipamento é o que, atualmente, está sendo utilizado no Brasilpe la maioria das instituições de pesquisa, que se dedicam ao es tudo da erosão.

Simuladores-de-chuva mais sofisticados, com variação automática da intensidade da chuva, durante sua apli cação, jā foram desenvolvidos e estão sendo utilizados em tra balhos de campo (FOSTER et alii, 1979 e NEYER \& HARMON, 1979).

o cálculo do potencial erosivo da chuva é normalmente feito pelo parâmetro $E_{30}$, produto da energia cinética pela intensidade máxima da chuva em 30 minutos. Este parâmetro representa o efeito da erosão por impacto, salpico e turbulência, combinado, ainda, com a capacidade de transporte da enxurrada. A energia cinética, em toneladas força pés por 
polegada acre, é determinada pela seguinte fórmula: $916+331$ $\log \mathrm{X}$; onde $\mathrm{X} \overline{\mathrm{e}}$ a intensidade da chuva em polegadas por hora (WISCHMEIER e SMITH, 1958). Essa equação é derivada dos dados de LAWS e PARSONS (1943) sobre a distribuição de tamanho das gotas da chuva para diferentes intensidades e dos valores da velocidade terminal de vários tamanhos de gotas d'água, medidos por LAWS (1941) e por GUNN \& KINZER (1949).

Um número crescente de trabalhos (BEST, 1950; MASON \& ANDREWS, $1960 ;$ HUDSON, 1971; KINNELL, 1973, CARTER et alii, 1974 e McEREGOR \& MUTCHLER, 1976), vem comprovando que a variação da distribuição do tamanho das gotas com a intensidade é diferente conforme o tipo de formação da chuva (frontal, convectiva e orogräfica) e com a localidade geográfica (latitude, altitude, continentalidade, etc.).

No Nordeste do Brasil, LEPRUN (1984) encontrou diferenças de distribuição de tamanho de gotas com a intensidade, entre as chuvas do Sertão Semi-Ārido e as da Zona da Ma ta, que apresenta clima tropical chuvoso.

Variações da relação entre erosividade e quantidade de chuva foram, também, observadas. por CHAVES e DINIZ (1980) e LEPRUN (1981) para diferentes tipos climáticos e 1ocalidades geogräficas do nordeste brasileiro.

CHAVES (1977) observou, para o município de Areia, no Estado da Paraíba, onde predominam chuvas orográficas, variações da relação entre erosividade e quantidade de chuva nos meses de outono e inverno. Tal fato pode ser justi 
ficado por variações dos processos de formação das chuvas, cu ja diversidade é decorrente da complexidade cilimática da Região, caracterizada pela predominância de flutuações de massas de ar e o efeito orográfico exercido pelo planalto da Bor borema.

Essas constatações sugerem que futuros traba1hos sejam desenvolvidos em diferentes regiões climáticas do Brasil, com a finalidade de se obterem informações das características de chuva, tanto para o cálculo do potencial erosivo como para o desenvolvimento de equipamentos que melhor simulem as chuvas locais.

Diferentes métodos podem ser utilizados para a avaliação das características de chuva. MEYER (1958) e HUDSON (1964) apresentaram uma revisão destes métodos, que podem ser relacionados de acordo com as suas finalidades, em: métodos de avaliação da distribuição do tamanho das gotas e métodosde avaliação da velocidade de queda das gotas.

A distribuição de tamanho das gotas é, tradicionalmente, avaliada por materiais absorventes, tais como: o papel de filtro simples, ou tratado com corantes ou com emulsões de sais que reagem com a ägua. Outro método é o da captä ção das gotas por material pulverulento que, com a água, forma pelotas, cujo tamanho guarda uma relação definida com o ta manho das gotas que 1 hes deram origem. Farinha de trigo e gesso oño materiais mais usados. Esses métodos, pela sua simplicidade e precisão, servem normalmente como pa- 
drão para os demais que utilizam equipamento eletrônico, sono ro, fotogrä́fico, fotoelétrico ou radar.

A velocidade de queda das gotas é facilmente medida pela cronometragem do tempo gasto pelas gotas para per correrem uma determinada distância. Contudo, equipamentos ele trônicos, fotogrä́ficos e fotoelétricos podem ser utilizados, dando melhor precisão às medidas. o cālculo teórico pode ser empregado; embora variações da forma das gotas em queda, prin cipalmente daquelas com diâmetros superiores a $3,0 \mathrm{~mm}$, possibilitem êrros consideráveis.

o trabalho pioneiro que utilizou o método fotográfico no estudo das características da chuva foi o de Mache, em 1904, o qual serviu de base, quarenta anos depois, ao trabalho de LAWS (1941). Ambos só mediram a velocidade de que da das gotas. A determinação simultânea do tamanho e velocida de de queda das gotas foi tentada por Laws; embora problemas de refração da luz, associados à posição das gotas no campo fotográfico, tenham prejudicado a obtenção dos dados de tamanho de gotas, com suficiente precisão.

GREEN (1952) substituindo, no método de Laws, os refletores por um "flash" eletrônico, obteve medidas de tamanho e velocidade de queda de gotas produzidas por um bico aspersor de irrigação com razoável precisão. 


\begin{abstract}
Equipamentos utilizando "flash" eletrônico e a mesma técnica fotogrä́ica empregada por Laws (fotografia sobre fundo escuro) foram utilizados por Jones \& Dean (HUDSON, 1964) e por CANNON (1970) para fotografar gotas de chuva natural, com sucesso.
\end{abstract}




\section{MATERTAL E METODO}

Com a finalidade de se alcançarem os objetivos propostos, foram feitas anālises volumétricas e fotográficas do jato de aspersão de bicos Veejet 80.100 utilizados em simu 1 adores-de-chuva.

Nestas anālises manteve-se a pressão de 6 psi; ou seja, $0,42 \mathrm{kgf} . \mathrm{cm}^{-2}$, que é a recomendada para a operação destes equipamentos.

\subsection{Anālises Volumëtricas}

Estas anālises compreendem as da vazão total e as das vazões parciais. Em ambas, foram utilizadas 10 bicos aspersores Veejet 80.100 do simulador-de-chuva do Instituto Agronômico do Estado de São Paulo, escolhidos ao acaso, dentre os 30 utilizados no aparelho. 


\subsubsection{Vazão Total}

Neste ensaio, foi utilizado um recipiente de volume conhecido e um cronômetro.

A vazão foi expressa em litros por minuto e foram feitas leituras de vazão com 8 repetições, em cada bico aspersor analisado.

Obtiveram-se 80 valores de vazão ( 10 aspersores $x 8$ repetições), com os quais se avaliou o controle dequa lidade dos aspersores, determinando-se o intervalo de confiança da média das vazões, com um coeficiente de confiança de $95 \%$ de probabilidade, cujos extremos são obtidos por:

$$
\bar{x} \pm t \frac{s}{\sqrt{n}}
$$

onde:

$\bar{x}=$ média da amostra,

$s=$ desvio padrão,

$\mathrm{n}=$ números de repetições;

$t=$ variável que depende do número do grau de liberdade e da probabilidade de confiança desejada para o intervalo.

3.1.2. Vazões Parciais

Neste ensaio foram utilizados 9 recipientes, um cronômetro e uma proveta graduada de $1000 \mathrm{ml}$.

Os recipientes tinham a forma de um funil de 
boca retangular, medindo $10 \mathrm{~cm}$ de largura por $60 \mathrm{~cm}$ de comprimen to e eram providos de um copo coletor de 1,51 . Estes recipientes foram distribuidos transversalmente ao jato de asper são, em pontos equidistantes, sobre um estrado de ferro de $2,4 \mathrm{~m}$ de comprimento (Figura 1).

os volumes colhidos por unidade de tempo, em cada ponto de observação, convertidos para valores percentuais da vazãototal de cada bico aspersor, deram as vazões de cadà uma das 9 seções do jato de aspersão.

A altura dos aspersores, para a obtenção destes dados, foi de $2,4 \mathrm{~m}$ acima do plano horizontal em que estavam instalados os coletores, que é a altura de queda recomendada por MEYER (1958).

Obtiveram-se 540 dados de vazão (10 aspersores x 9 pontos de observação x 6 repetições), com os quais determinou a distribuição média da vazão ao longo do leque de aspersão e a homogeneidade de distribuição das vazões, em cada seção, em relação aos respectivos valores médios.

Como critério de homogeneidade da vazão, adotou-se o intervalo de um desvio padrão em torno da média, em cada seção do jato de aspersão. Os bicos aspersores com vazões em todas as seções do jato de aspersão, dentro do intervalo, foram considerados como tendo uma distribuição simétrica. 


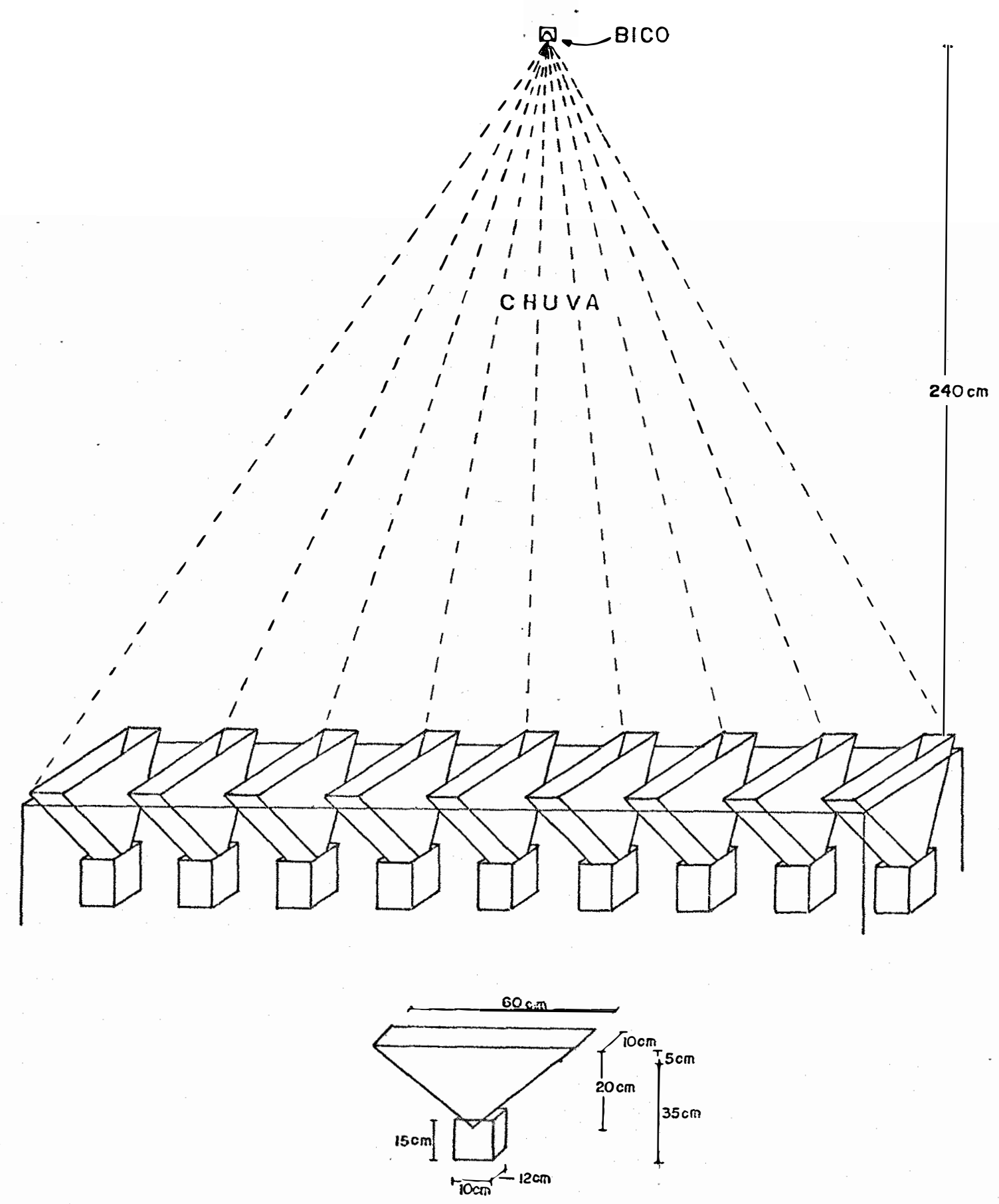

Figura 1. Estrado com funis coletores utilizados na avaliação da distribuição da vazão dos bicos aspersores. 


\title{
3.2. Anālises Fotogräficas.
}

\begin{abstract}
Para estas análises, foi montado um estúdio fó tográfico de acordo com o esquema representado na Figura 2.

o método foi o utilizado por Mache, em 1904 (LAWS, 1941), que, com algumas adaptações, permitiu avaliar o tamanho e a velocidade das gotas de chuva.
\end{abstract}

\subsubsection{Estúdio Fotogräfico}

Constou de uma câmara fotográfica profissional de $35 \mathrm{~mm}$, equipada com uma lente de aproximação de $200 \mathrm{~mm}$ e filmes pancromáticos, em branco e preto, de alta sensibilida de (400 ASA). Na frente da câmara fotogräfica, um disco negro rotativo, com 16 janelas serviu de obturador de imagem. Um pequeno motor elétrico, ligado a uma corrente estabilizada, acionava o disco a 1492 r.p.m., proporcionando uma velocidade de obturação de aproximadamente $1 / 398 \mathrm{~s}$.

Para medir a rotação do motor, foi utilizadoum pequeno circuito elétrico, alimentado por uma pilha de 9 volts, ao qual foi instalada uma fotocélula LDR (Light Dependent Resistance). Quando sensibilizada pela luz, esta fotocélula diminui a sua resistência à corrente, gerando impulsos elétricos que foram contados por uma frequencímetro digital. Desta forma, instajou-se uma lâmpada direcionada à fotocélu- 


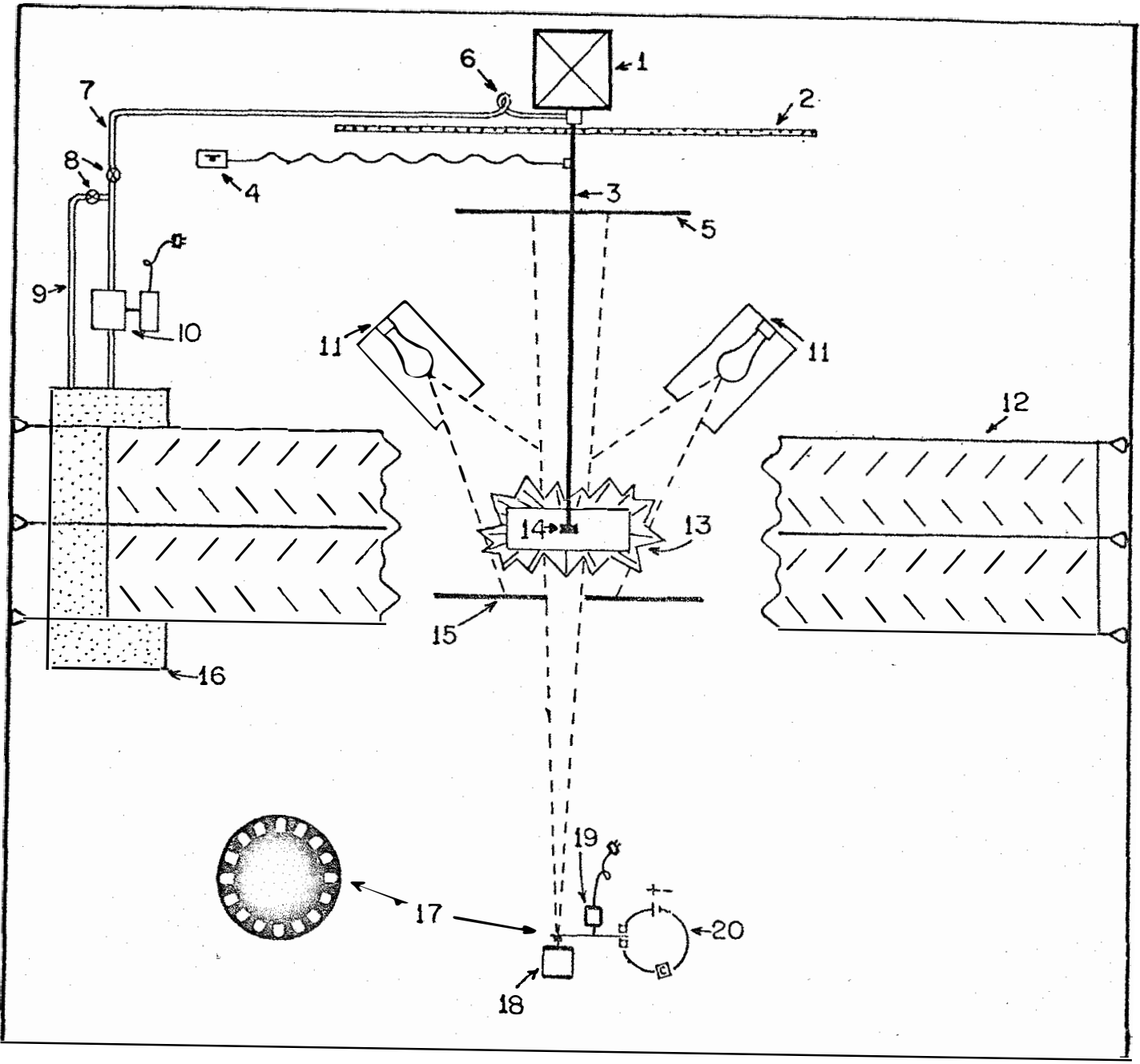

1 - torre de ferro com $6 \mathrm{~m}$ de altura

2 - suporte transversal ảo braço móvel

3 - braço móvel

4 - manometro de mercúrio ligado ao cano de suporte do bico aspersor, localizado sobre o braço móvei

5 - fundo escuro

6 - mangueira piästica de ligação dos canos

7 - canos PVC

8 - registros de controle da pressão

9 - retorno

10 - moto-bomba

11 - lâmpadas "Photoflood/ № 2, $500 \mathrm{w}$

12 - canal coletor

13 - janela de captação da chuva

14 - bico aspersor

15 - anteparo da luz contra a máquina fotográfica

16 - reservatório de alimentação e captaçãod 'água

17 - disco obturador

18 - mäquina fotcgráfica

19 - motor clétrico do disco obturador

20 - circuito elétrico ( $9 \mathrm{~V})$ com fotocélula e frequencímetro, para medição da velocidade de. obturação.

Figura 2. Planta baixa do estüdio fotográfico. 
1a, através das janelas do disco obturador, para se obter o nūmero de exposições por segundo, ou, a velocidade de rotação do disco.

Um anteparo com abertura de $25 \times 30 \mathrm{~cm}$, foi posto entre a câmara e o campo fotográfico, permitindo que apenas a luz refletida pelas gotas atingisse, indiretamente, a objetiva da câmara fotogräfica. Dois refletores com lâmpadas "Photoflood" no 2 de $500 \mathrm{~W}$, foram dispostos lateral e posteriormente ao campo fotogrä́fico, formando um ângulo de 45 o com o eixo da câmara. Atrás da linha dos refletores, foi posto um fundo escuro, com o qual as gotas iluminadas faziam con traste.

Para sustentar os bicos aspersores, nas diferentes alturas e posições, foi montada uma torre de ferro com 6 m de altura, onde se deslocava verticalmente um travessão e sobre este, com deslocamento horizontal, um braço onde foram instalados individualmente os bicos aspersores.

o sistema hidráulico era composto de um reservatório de 3001 instalado ao nível do solo, uma bomba modelo 40 D de 540 rpm acionada por um motor elétrico de 1 CV e 2 ca nos de PVC de $1 / 2$ polegada, interligados por uma mangueira plástica flexível. Um destes canos ia da bomba à base da torre e o outro, instalado sobre o braço móvel da torre, sustentava, individualmente em sua extremidade, os bicos aspersores.

o controle da pressão da ägua, na saída do as- 
persor, foi feito por meio de um manômetro de mercúrio instalado no chão, próximo ao reservatório e ligado ao cano onde es tava acoplado o aspersor, através de uma mangueira plástica.

As variações de pressão e consequentemente da vazão do aspersor, foram conseguidas através de dois registros de passagem; um que controlava o retorno da água ao reservatório, e o outro, a condução da água ao aspersor.

A amostragem da chuva foi feita por uma janela de captação de gotas, formada pela base superior de um tronco de pirâmide de $8 \mathrm{~cm}$ de largura e $20 \mathrm{~cm}$ de comprimento, instalada a $1,75 \mathrm{~m}$ do chão. Este tronco de pirâmide foi feito de chapa de ferro galvanizado nọ 28 e montado sobre uma armação de ferro em forma de mesa, embaixo da qual localizava-se o cam po fotográfico.

A chuva que não passava pela janela de captação era recolhida ao reservatório de alimentação do sistema, por gravidade, através de um canal. Esse canal foi feito de lona plástica e tinha uma seção transversal em forma de "W", tendo sido armado transversalmente ao eixo da câmara fotográfica e por cima da mesa de ferro, com uma declividade de $5 \%$, de forma que o tronco de pirâmide, que formava a janela de captação de gotas, ficava sobressaíndo no seu centro.

\subsubsection{Método Fotogrä́ico}

Neste método, as gotas ao cairem diante de um 
fundo escuro eram iluminadas, por trás e lateralmente, por duas fontes de luz, de acordo com a técnica de contraste que é comumente utilizada para fotografar corpos transparentes.

Cada gota foi registrada no filme na forma de uma coluna de pares de traços paralelos, resultantes do deslo camento de dois focos luminosos refletidos pela gota, provenientes das duas fontes luminosas incidentes e do seccionamen to da imagem feito pelas janelas do disco obturador (Figura 3a). Para cada coluna de imagens foram obtidos aproximadamente 3,2 pares de traços, resultantes da velocidade de $1 / 398 \mathrm{~s}$ do disco obturador e da velocidade de $1 / 125$ s selecionada para o obturador da máquina fotográfica.

A velocidade de queda das gotas foi determinada pela distância vertical entre os pares de traços da coluna e o tempo entre cada exposição.

o diâmetro das gotas, consideradas esféricas, foi tomado como sendo igual à distância horizontal entre os traços de um mesmo par de imagens.

As medições para a determinação da velocidade e do tamanho das gotas foram feitas na projeção das imagens do negativo sobre uma tela, com o auxílio de uma régua milime trada. Esta tela, foi feita com filme de poliester transparen te de $1 \mathrm{~m}^{2}$, montado em moldura de madeira, com uma concavidade de $6 \mathrm{~cm}$ de profundidade, no sentido horizontal, para compensar adistorção da imagem causada pela lente do aparelho projetor. A transparência 
do filme de poliester permitiu que se fizesse a medição das imagens, diretamente na tela do lado oposto ao da projeção.

A calibração do sistema fotográfico e da projeção da imagem foi feita comparando-se as leituras obtidas com a fotografia da escala decimal de uma mira de topografia.

\subsubsection{Avaliação do Método Fotográfico}

Para avaliar a precisão das leituras do tamanho e velocidade de queda das gotas d'água atravēs de suas imagens fotográficas, foi montado um ensaio utilizando-se gotas de diferentes diâmetros $(2,3 ; 3,1 ; 3,9$ e $5,2 \mathrm{~mm})$, caindo das alturas de $1,2,5,9$ e $12 \mathrm{~m}$.

Em cada tratamento, foram tiradas 4 fotografias, procurando-se obter, em cada chapa, um mínimo de 6 imagens de gotas. Foram feitas 3 leituras, tanto para determinar o diâmetro, como a velocidade de queda, em diferentes posições da coluna de pares de traços (Figura $3 b$ ); obtendo-se, aproximadamente, 72 leituras para cada uma das características.

Nem sempre as imagens dos traços foram perfeitas, apresentando, muitas vezes, extremidades pouco nítidas. Por esse motivo, as leituras verticais foram tomadas entre 3 pares de traços, a partir do centro, da extremidade ou da metade do intervalo entre os traços, de acordo, em cada ca so, com a facilidade de obtenção das leituras. 

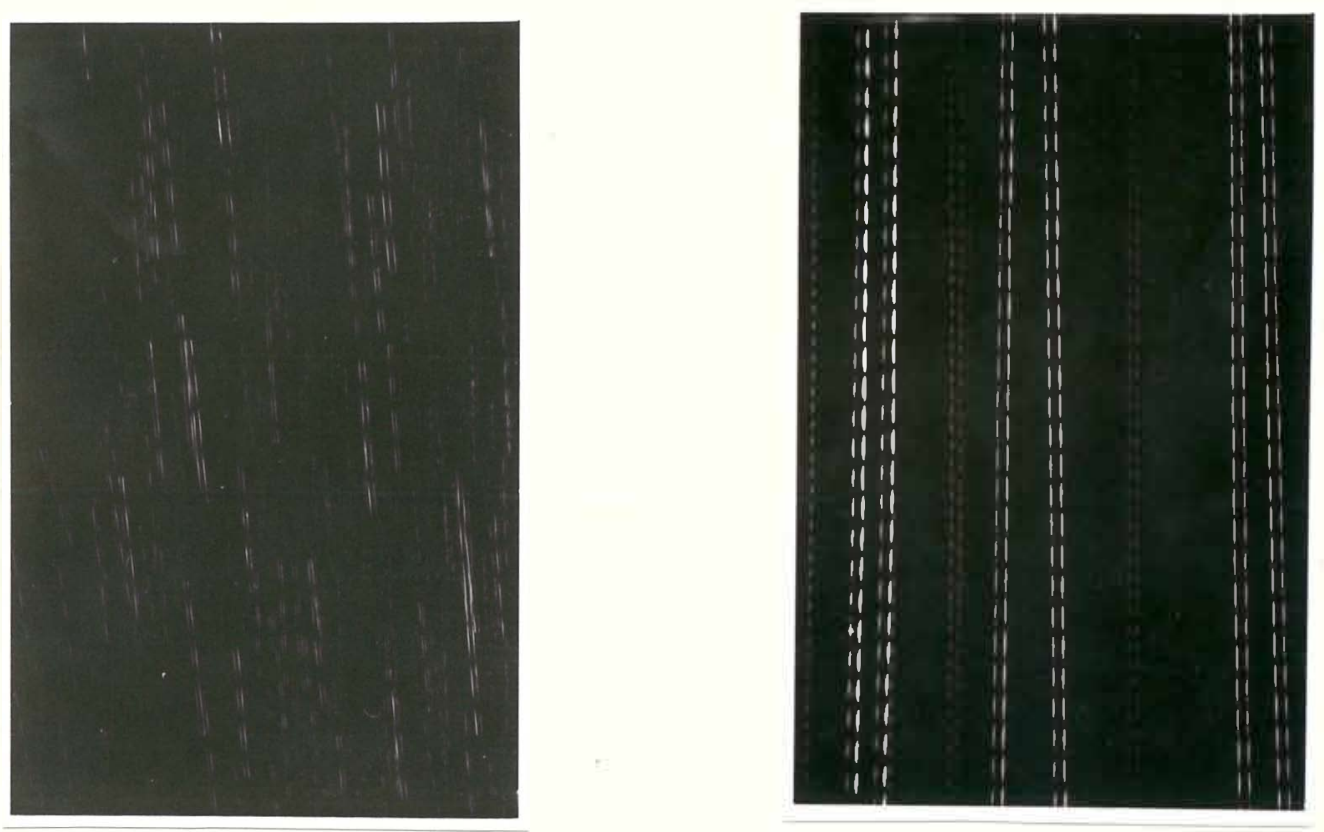

Figura 3. (a) Gotas de diferentes diâmetros dos ensaios com chuva simulada (b) Gotas d'ägua de 5,2 mm de diâmetro e gotas filhas ou satélites, dos ensaios para a calibração do sistema fotográfico.

Para cada diâmetro de gota e altura de queda relacionou-se a distância entre os focos refletidos pela gota (obtida na fotografia) com o diâmetro esférico (obtido por gravimetria) visando-se determinar fatores de correções para as leituras fotogräficas.

As velocidades de queda das gotas d'água, foram comparadas com os dados de LAWS (1941), uma vez que seus 
valores são amplamente aceitos e comprovados pelo trabalho de GUNN E KINZER (1949).

\section{Formação e determinação do diâmetro esférico das gotas d'āgua}

As gotas d'água foram obtidas com gotejádores de pequeno calibre, acoplados individualmente a um equipamen to composto de reservatório d'água, mangueira e estrangulador de vazão.

Para a determinação do diâmetro esférico das gotas foram pesadas 30 gotas, com 6 repetições, obtidas sempre com uma mesma frequência de formação ( $I$ gota/s para as go tas de $2,3 \mathrm{~mm}$ e 2,5 gotas/s para as demais). O peso médio das 6 repetições, dividido por 30 , deu o peso médio de uma gota, que corresponde ao seu volume, uma vez que se considerou a densidade da ägua igual a 1. A partir do volume das gotas (aplicando-se a fórmula do volume da esfera, $V=\frac{4}{3} \Pi R^{3}$ ), determinou-se os seus diâmetros esféricos.

Para a obtenção das gotas de menor diâmetro, devido à perda de carga no gotejador, foi necessária a aplica ção de uma pressão, obtida com a elevação do reservatório, pä ra que ocorresse o desprendimento das gotas.

Durante estas determinações procurou-se investigar a influência da temperatura da àgua (de 15 a 309 C) e da umidade relativa do ar.sobre o tamanho das gotas produzidas 
pelos gotejadores; mas, não se encontrou, para as condições do experimento, nenhuma correlação. Sendo assim, foi controla da apenas a frequência de formação das gotas e a qualidade da àgua utilizada (destilada).

3:3. Análise do Jato de Aspersão.

Neste ensaio, a composição de tamanho e as velocidades de queda das gotas de chuvas simuladas foram determinadas pelo método fotogräfico. Utilizaram-se 6 bicos aspersores e foram tiradas fotografias em 5 pontos equidistantesao longo do jato de aspersão, para alturas de queda de 2,3 e 4 m .

Após a anālise dos dados dos bicos para altura de $2 \mathrm{~m}$, constatou-se que a distribuição de tamanho das gotas tinha uma variação simétrica ao longo do jato de aspersão. Sendo assim, decidiu-se eliminar dois dos pantos simétricos de observação e dois dos bicos aspersores para os tra tamentos correspondentes às alturas de 3 e $4 \mathrm{~m}$.

Em cada tratamento, foram tiradas aproximadamente 6 fotografias, visando-se obter um mínimo de 60 imagens de gota, para a altura de queda de $2 \mathrm{~m}$ e de um mínimo de 35 imagens, para as alturas de 3 e $4 \mathrm{~m}$. 


\subsubsection{Tamanho das Gotas}

As gotas foram agrupadas em classes de tamanho de $0,5 \mathrm{~mm}$ de amplitude e representadas pelos diâmetros médios das classes. A velocidade das gotas em cada classe foi a média das velocidades das gotas que ali ocorreram. Em cada seção e altura de queda do jato de aspersão a distribuição percentual dos tamanhos e as velocidades das gotas foram as médias globais das distribuições dos tamanhos e velocidades de cada bico aspersor.

\section{Utilizando-se a função raiz quadrada para as} distribuições de tamanho de gotas encontradas, foi feito um estudo do ajustamento dos dados à distribuição normal, estimando-se, en tão, os novos valores percentuais para as classes de tamano de gotas.

Em seguida, está apresentado um exemplo do pro cedimento, com os dados da seção 1 , correspondentes à extremi dade do jato de aspersão para a altura de $2 \mathrm{~m}$ :

\begin{tabular}{llrrrr}
\hline c1asses & $\mathrm{PM}(1)$ & $\sqrt{\mathrm{PM}_{\mathrm{i}}}$ & $\mathrm{f}_{\mathrm{i}}(2)$ & $\sqrt{\mathrm{PM}} \cdot \mathrm{f}_{\mathrm{i}}$ & PM.f $_{\mathrm{i}}$ \\
\hline $0,5-1,0$ & 0,75 & 0,87 & 30 & 26,10 & 22,5 \\
$1,0-1,5$ & 1,25 & 1,12 & 225 & 252,00 & 281,3 \\
$1,5-2,0$ & 1,75 & 1,32 & 377 & 497,64 & 659,8 \\
$2,0-2,5$ & 2,25 & 1,50 & 226 & 339,00 & 508,5 \\
$2,5-3,0$ & 2,75 & 1,66 & 112 & 185,92 & 308,0 \\
$3,0-3,5$ & 3,25 & 1,80 & 24 & 43,20 & 78,0 \\
$3,5-4,0$ & 3,75 & 1,94 & 6 & 11,64 & 22,5 \\
\hline
\end{tabular}

(1) PM - Ponto médio da classe

(2) fi - Frequência de ocorrência 


$$
\begin{aligned}
& \bar{x}=\sum_{i=1}^{7} \frac{\sqrt{\mathrm{PM}_{i}} \cdot f_{i}}{\sum f_{i}}=\frac{1355,5}{1000}=1,355 \\
& s^{2}=\frac{1}{n-1}\left[\sum(P M) \cdot f_{i} \frac{\sum \sqrt{P M} \cdot f_{i}}{\sum f_{i}}\right] \\
& s^{2}=\frac{1}{999}(1880,5-1837,38) \cdot \cdot s^{2}=0,043 \text { e } s=0,208 .
\end{aligned}
$$

\begin{tabular}{ccccc}
\hline$\sqrt{1 \text { im }}(1)$ & $z^{(2)}$ & Prob. & Freq.Esp. & Freq.Obs. \\
\hline 0,71 & $-3,101$ & 0,4990 & & \\
1,00 & $-1,707$ & 0,4564 & 4,26 & 3,0 \\
1,22 & $-0,649$ & 0,2422 & 21,42 & 22,5 \\
1,41 & 0,264 & 0,1026 & 34,48 & 37,7 \\
1,58 & 1,082 & 0,3599 & 25,73 & 22,6 \\
1,73 & 1,803 & 0,4641 & 10,42 & 11,2 \\
1,87 & 2,476 & 0,4934 & 2,93 & 2,4 \\
2,00 & 3,101 & 0,4990 & 0,56 & 0,6
\end{tabular}

(1) Raiz quadrada dos limites das classes

(2) $z=\frac{x_{i}-\bar{x}}{s} \therefore x_{i}=\sqrt{1 i m}$

(3) Probabilidades de Z, valores tabelados

Verificação do ajustamento das distribuições:

a) Hipötese - se $x_{c a l}^{2}$ for menor que $x_{t a b}^{2}$ a dis tribuição é normal.

b) $x_{t a b}^{2}$, a nível de $5 \%$ de probabilidade

c) $\mathrm{x}_{\mathrm{cal}}^{2}=\sum_{i=1}^{\mathrm{n}} \frac{\left(\mathrm{Fo}_{i}-\mathrm{Fe}_{i}\right)^{2}}{\mathrm{Fe}_{i}}$

d) Conclusão - Como $x_{t a b}^{2}$ foi maior que $x_{c a l}^{2}$, os dados obedecem podem ser estudados como se tivessem uma distribuição normal. 


\subsubsection{Velocidade das Gotas}

Nesse caso, linearizaram-se as curvas de velocidade $x$ tamanho de gota, e para cada seção a altura dé queda do jato de aspersão se determinou a equação da curva de ajustamento dos dados. Com este procedimento foi possível estimar os valores ajustados de velocidade para as diferentes classes de tamanho de gota.

Em seguida será apresentado um exemplo do procedimento, utilizando-se os dados da seção l, da extremidade do jato de aspersão, para a altura de $2 \mathrm{~m}$ :

$$
y=a \cdot x^{b} \quad \because \quad \log y=\log a+b \log x, \quad \text { ou }
$$

(Equação da curva) (Equação da reta)

\begin{tabular}{|c|c|c|c|c|}
\hline $\begin{array}{c}\text { Tamanho } \\
\mathrm{x}\end{array}$ & $\begin{array}{r}\text { de Gota } \\
\log x\end{array}$ & $\begin{array}{c}\text { Ve locidade } \\
y\left(m_{.}-1\right) \rightarrow\end{array}$ & $\begin{array}{c}\text { da Gota } \\
\log y\end{array}$ & $\underset{\widehat{y}}{\operatorname{Ve} 1 . E s t i m a d a}$ \\
\hline 0,75 & $-0,1249$ & 5,70 & 0,756 & 5,88 \\
\hline 1,25 & 0,0969 & 6,63 & 0,822 & 6,59 \\
\hline 1,75 & 0,2430 & 7,32 & 0,865 & 7,10 \\
\hline 2,25 & 0,3522 & 7,75 & 0,889 & 7,51 \\
\hline 2,75 & 0,4393 & 7,91 & 0,898 & 7,85 \\
\hline 3,25 & 0,5118 & 8,17 & 0,912 & 8,15 \\
\hline 3,75 & 0,5740 & 8,01 & 0,904 & 8,41 \\
\hline
\end{tabular}

Donde,

$$
\begin{gathered}
\hat{Y}=0,7973+0,2221 x, \text { ou, aplicando o antilogaritmo } \\
\hat{y}=6,2705 \cdot x^{0,2221} \\
\text { com } r^{2}=0,946^{++}
\end{gathered}
$$




\subsubsection{Energia Cinética}

Com os dados ajustados da distribuição de tama nho e velocidade de queda das gotas, procedeu-se ao cálculo da energia cinética.

$$
\text { Sabe-se que: } E c=1 / 2 \mathrm{M} \cdot \mathrm{V}^{2}
$$

Para $1 \mathrm{~mm}$ de altura de precipitação (h) sobre um hectare $\left(A=10.000 \mathrm{~m}^{2}\right)$ tem-se um volume (V) de $10 \mathrm{~m}^{3}$, que corresponde, para ägua, a massa (M) de 10.000 kg. Ou, dividindo-se pela aceleração da gravidade padrão （ $\mathrm{g}=$

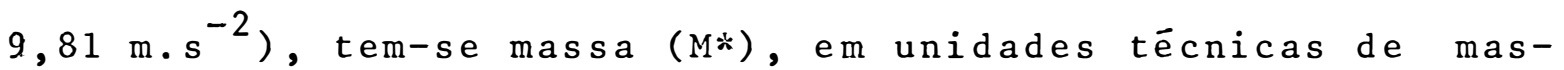
sa, ou seja:

$$
\begin{aligned}
& \mathrm{V}=\mathrm{h} \cdot \mathrm{A} \cdot V \mathrm{~V}=0,001 \mathrm{~m} \cdot 10000 \mathrm{~m}^{2} \cdot \because \mathrm{V}=10 \mathrm{~m}^{3} \\
& M=\mathrm{V} \cdot \mathrm{d} \cdot \because \mathrm{M}=10 \mathrm{~m}^{3} \cdot 1 \mathrm{t} \cdot \mathrm{m}^{3} \cdot \because \mathrm{M}=10.000 \mathrm{~kg} \\
& M *=\frac{M}{\mathrm{~g}}=\frac{10.000 \mathrm{~kg}}{9,81 \mathrm{~m} \cdot \mathrm{s}^{-2}}=1019,4 \mathrm{u} \cdot \mathrm{t} \cdot \mathrm{m} .
\end{aligned}
$$

Sendo $E c=1 / 2 M * \cdot V^{2}$. Como cada classe de gotas contribui com uma fração $h_{i}$ da precipitação, sua energia cinética $\left(E_{i}\right)$ será calculada pela fórmula:

$$
\begin{aligned}
& \mathrm{Ec}_{i}=1 / 2 \cdot 1,0194 \cdot \mathrm{h}_{i} \cdot \mathrm{v}_{i}^{2}, \text { ou seja, } \\
& \mathrm{Ec}_{i}=509,7 \mathrm{~h}_{\mathrm{i}} \cdot \mathrm{v}_{i}^{2} \cdot \therefore \mathrm{Ec}=\sum \mathrm{Ec}_{\mathrm{i}} \\
& \text { em } \mathrm{kg} * \mathrm{~m} \cdot \mathrm{ha}^{-1} \cdot \mathrm{mm}^{-1}, \text { ou em unidades mil vezes maior, } \\
& \text { em } \mathrm{t} * \mathrm{~m} \cdot \mathrm{ha}^{-1} \cdot \mathrm{mm}^{-1} .
\end{aligned}
$$


Ficando como mostra o quadro abaixo, para os dados da seção 1 , da altura de $2 \mathrm{~m}$.

\begin{tabular}{|c|c|c|c|c|c|c|}
\hline $\begin{array}{c}\overline{\mathrm{D}} \\
(\mathrm{mm})\end{array}$ & $\begin{array}{c}\text { Gotas } \\
\%\end{array}$ & $\begin{array}{c}\text { Vol. Unit. } \\
\left(\mathrm{mm}^{3}\right)\end{array}$ & $\begin{array}{c}\text { Vol.Classe } \\
\quad\left(\mathrm{mm}^{3}\right)\end{array}$ & $h_{i}{ }^{(*)}$ & $\begin{array}{c}v_{i} \\
\left(m \cdot s^{-1}\right.\end{array}$ & 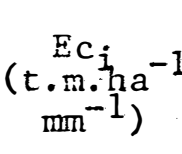 \\
\hline 0,75 & 4,27 & 0,2209 & 0,943 & $0 ; 0021$ & 5,88 & 0,038 \\
\hline 1,25 & 21,42 & 1,0227 & 21,906 & 0,0481 & 6,59 & 1,064 \\
\hline 1,75 & 34,48 & 2,8062 & 96,758 & 0,2123 & 7,10 & 5,429 \\
\hline 2,25 & 25,76 & 5,9641 & 153,456 & 0,3367 & 7,51 & 9,678 \\
\hline 2,75 & . $\quad 10,42$ & 10,8892 & 113,465 & 0,2489 & 7,85 & 7,820 \\
\hline 3,25 & 22,93 & 17,9742 & 52,664 & 0,1156 & 8,15 & 3,912 \\
\hline \multirow[t]{2}{*}{3,75} & 0,60 & 27,6116 & 16,567 & 0,0364 & 8,41 & 1,308 \\
\hline & 100,00 & & 455,759 & 1,0000 & $E c=$ & 29,250 \\
\hline
\end{tabular}

(*) $\mathrm{h}_{i}=$ fração correspondente ao volume de cada classe de tamanho de gota para $1 \mathrm{~mm}$ de precipitação.

\subsection{Caracteristicas do Simulador-de-chuva}

O simulador-de-chuva de braços rotativos, desenvolvido por SWANSON (1965), consta de uma base montada sobre um chassi com 4 rodas pneumáticas, onde fica o motor de acionamentio, o sistema de transmissão e uma haste central, em cuja extremidade superior se acoplam 10 canos, dispostos horizontalmente e de forma radial. Cada cano possui 3 bicos as persores, dando ao conjunto um total de 30 bicos, os quais são posicionados em raios de 1,$50 ; 3,00 ; 4,50 ; 6,00$ e 7,50 m 
em relação a haste central, $\operatorname{com} 2,4,6,8$ e 10 bicos em cada raio, respectivamente, conforme a Figura 4. A partir de um reservatório de àgua, natural ou artificial, uma moto-bomba recalca a água através de um conduto, alimentando o simulador. 0 conjunto de canos gira, de 3,5 a 4,0 rpm, movimentado pelo motor do simulador e a chuva artificial é projetada ao solo através dos bicos aspersores.

As parcelas experimentais para o trabalho com o simulador-de-chuva rotativo devem ter $3,5 \mathrm{~m}$ de 1 argura por $11 \mathrm{~m}$ de comprimento e a declividade de 5 a $9 \%$ (EMBRAPA/IAPAR, 1975). Dessa forma, na condição de declividade máxima recomendada (9\%), ter-se-iam, sobre a parcela experimental, alturas que variam de 2,25 a $3,25 \mathrm{~m}$ (Figura 4). Em muitas pesqui sas, em solos declivosos ou quando se utilizam plantas de por te alto, esses limites de altura são ultrapassados. Porisso, neste trabalho, foram estudadas as caracteristicas do jato de aspersão de bicos nacionais Veejet 80.100 para as alturas de 2,3 e $4 \mathrm{~m}$.

3.5. Cálculo da Erosividade da Chuva Simulada

A erosividade da chuva simulada foi calculada pelo indice de erosão $\left(\mathrm{EI}_{30}\right)$, proposto por WISCHMEIER \& SMITH (1958), obtido pela expressão:

$$
\mathrm{EI}_{30}=\mathrm{E} \times \mathrm{P} \times \mathrm{I}_{30} \times 10^{-3}
$$



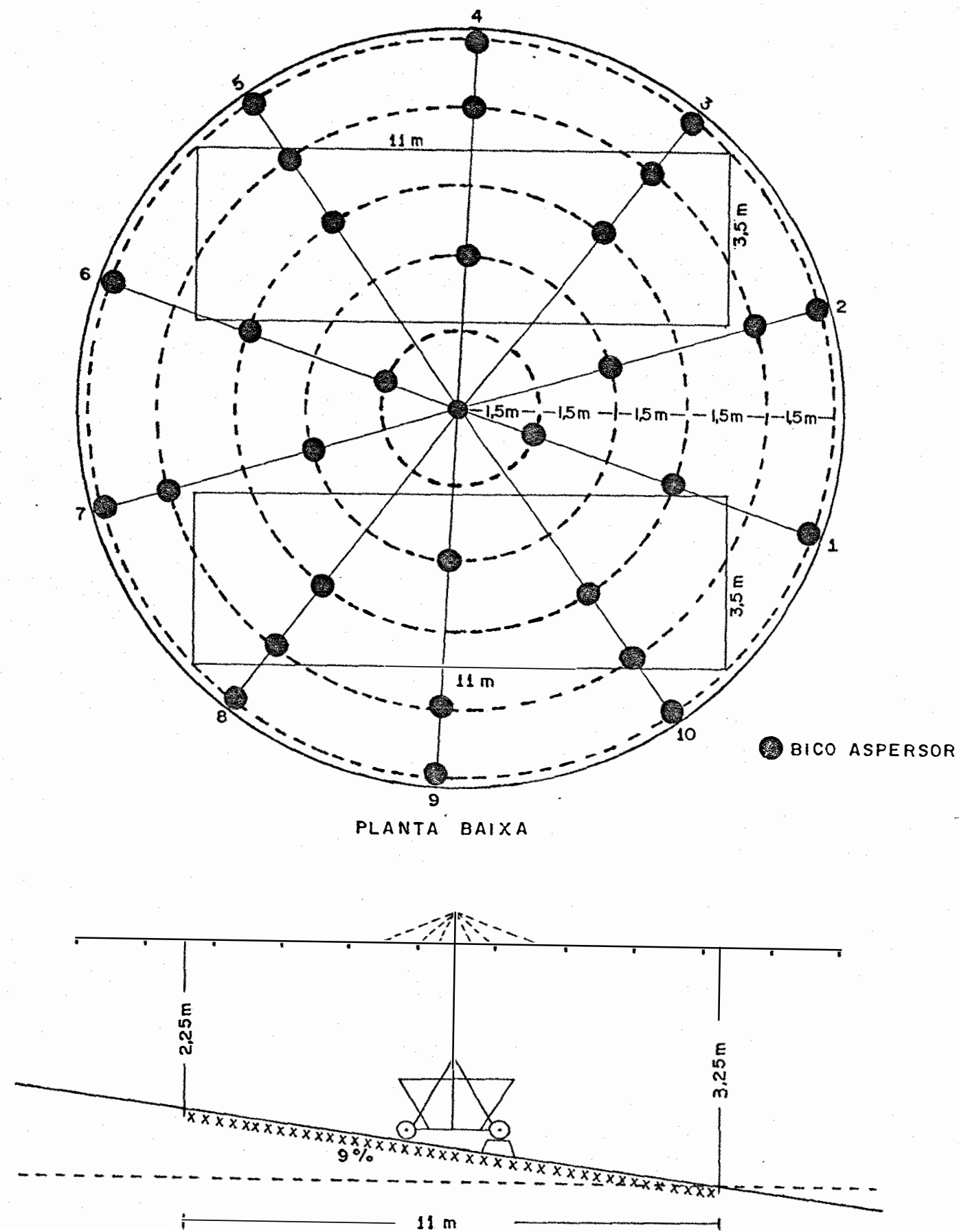

VISTA LATERAL

Figura 4. Distribuição dos bicos aspersores no simulador-dechuva, parcelas experimentais e alturas de aplicação da chuva simulada, para declividade de $9 \%$. 
onde: $\operatorname{EI}_{30}$ - indice de erosão $\left(t \mathrm{~m} \cdot \mathrm{mm} \cdot \mathrm{ha}^{-1} \cdot \mathrm{h}^{-1}\right)$;

$E \quad=$ energia cinética da chuva $\left(t m \cdot h a^{-1} \cdot \mathrm{mm}^{-1}\right)$;

$P \quad=$ precipitação $(\mathrm{mm})$;

$I_{30}=$ precipitação máxima em 30 min, expressa em milímetro por hora;

$10^{-3}=$ fator de proporcionalidade.

Na chuva simulada a variação da intensidade da chuva é obtida pela variação do nümero de bicos aspersores em funcionamento. Com isso, como não varia a pressão da água nos bicos aspersores, para uma determinada altura de queda, a energia cinética por unidade de altura de chuva, não variará.

A hipótese deste trabalho era que a energia cí nética da chuva simulada variasse com a altura de queda, devido às modificações das velocidades das gotas; contudo, embora essas modificações ocorram ao longo do jato de aspersão, o valor médio da energia cinética permanece praticamente o mesmo; isto é, $30,3 \mathrm{tm} \cdot \mathrm{ha}^{-1} \cdot \mathrm{mm}^{-1}$ (Tabela 5).

Os bicos nacionais $\left(22,91 . \mathrm{min}^{-1}\right.$ a 0,42 Kgf. $\mathrm{cm}^{-2}$ ) produzem chuvas com intensidades de 94 e $188 \mathrm{~m} \cdot \mathrm{h}^{-1}$, para 15 e 30 bicos em funcionamento. Sendo assim, para uma chu va de $94 \mathrm{~mm} \cdot \mathrm{h}^{-1}$, com duração de $60 \mathrm{~min}$, tem-se uma quantidade de chuva (P), de $94 \mathrm{~mm}$ e uma intensidade máxima ( ( $_{30}$ ), também, de $94 \mathrm{~mm} \cdot \mathrm{h}^{-1}$, com o seguinte potencial erosivo:

$$
\mathrm{EI}_{30}=30,3 \times 94 \times 94 \times 10^{-3} \cdot \mathrm{EI}_{30}=267,7 \mathrm{tm} \cdot \mathrm{mm} \cdot \mathrm{ha}^{-1} \cdot \mathrm{h}^{-1}
$$


Da mesma forma, para um mesmo tempo de duração, uma chuva de $188 \mathrm{~mm} \cdot \mathrm{h}^{-1}$ terá um $\mathrm{P}$ de $188 \mathrm{~mm}$ e um $I_{30}$ de $188 \mathrm{~mm} \cdot \mathrm{h}^{-1}$, produzindo uma erosividade de 1070,9 tm.mm.ha $a^{-1} \cdot \bar{h}^{-1}$. 


\section{RESULTADOS E DISCUSSÃO}

os resultados obtidos das anälises volumétricas e fotográficas da chuva simulada produzida por bicos aspersores Veejet 80.100 estão apresentados e discutidos a seguir.

\subsection{Vazão dos Bicos Aspersores}

o simulador-de-chuva tipo rotativo, objeto des te estudo, foi desenvolvido por SWANSON (1965), a partir das informações de vazão dos bicos aspersores "Veejet 80.100" testados por MEYER (1958).

\subsubsection{Vazão Total}

Esta característica, dependendo da intensidade da chuva a ser aplicada, determina a ärea a ser coberta por cada bico aspersor e consequentemente, o número destes no aparelho. 
No simulador-de-chuva tipo rotativo, cada bico aspersor com vazão de $14,81 . \mathrm{min}^{-1}$, cobre uma ärea de 7,3 e de $14,6 \mathrm{~m}^{2}$ para produzir chuvas com intensidades de 122 e de $61 \mathrm{~mm} \cdot \mathrm{h}^{-1}$, respectivamente. 0 aumento do número de bicos, de 15 para 30 , que entram em funcionamento e não o aumento da va zão dos bicos aspersores é que faz aumentar a intensidade da chuva simulada (SWANSON, 1965).

Para uma mesma pressão de funcionamento $(0,42$ Kgf.cm ${ }^{-2}$ ), observa-se, na Figura 5, que os bicos aspersores nacionais produzem uma vazão de 8,11 a mais do que os bicos aspersores americanos. Sendo assim, pode-se afirmar que os bicos nacionais trabalham com uma pressão menor do que 0,42 Kgf.cm- $\mathrm{cm}^{-2}$; uma vez que os simuladores-de-chuva brasileiros têm o mesmo dimensionamento e são calibrados para aplicar as mesmas intensidades de chuva que os americanos. Pressão de 0,29 Kgf.cm ${ }^{-2}$, medida na torre do aparelho e consequentemente superestimando a pressão de vazão nos bicos aspersores, foi uti lizada por SAUNDERS et alii (1981b) para obterem intensidades de $60 \mathrm{~mm} \cdot \mathrm{h}^{-1}$ e $120 \mathrm{~mm} \cdot \mathrm{h}^{-1}$, em dois simuladores-de-chuva do tí po rotativo de fabricação nacional. A pressão de funcionamento dos bicos aspersores é um dado importante, uma vez que a velocidade de queda e a distribuição do tamanho das gotas são modificadas, alterando, consequentemente, a erosividade da chuva simulada.

Os bicos aspersores nacionais apresentam vazões muito irregulares. Na Figura 6 , observa-se que $40 \%$ das 


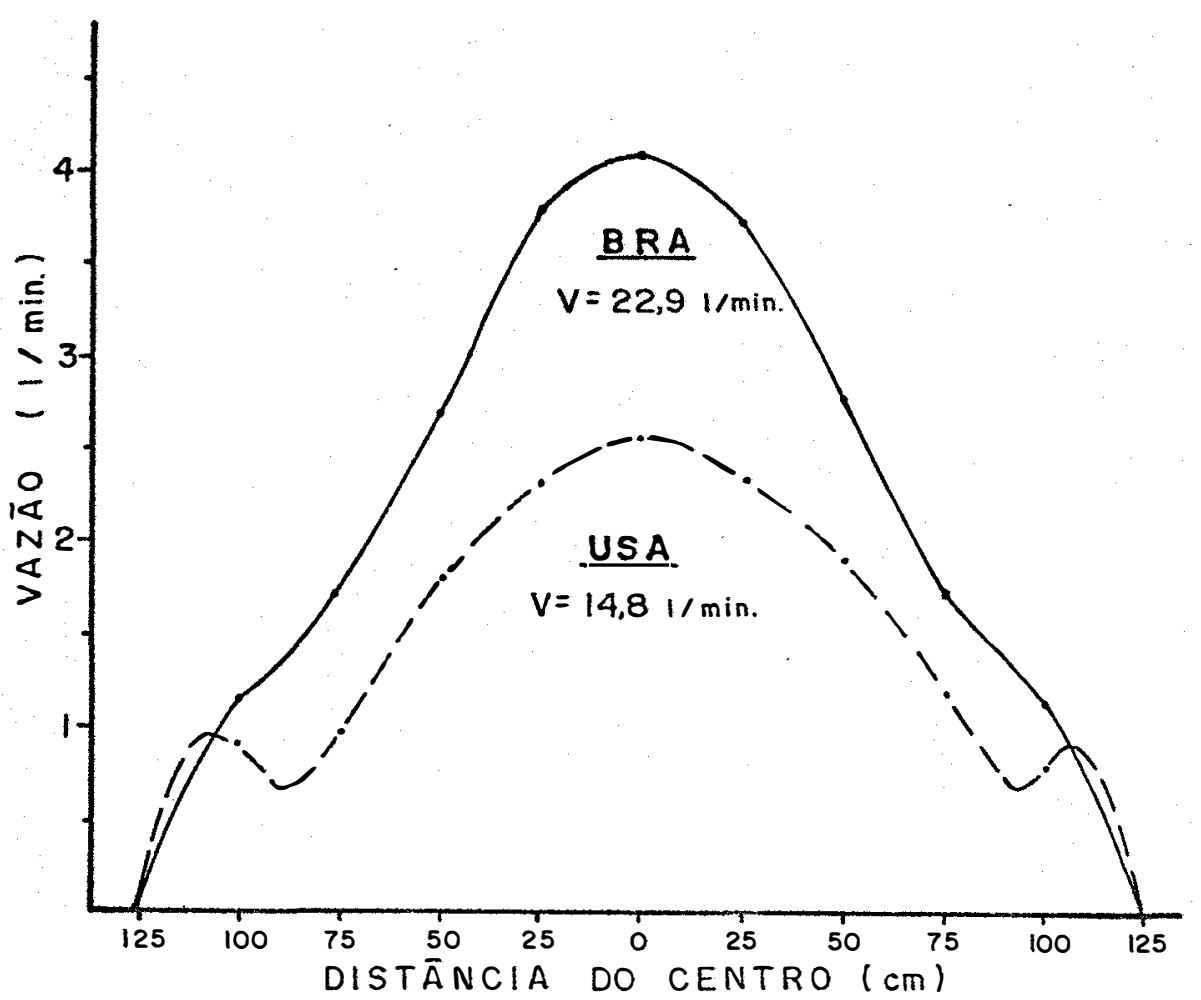

Figura 5. Distribuição da vazão de bicos aspersores Veejet 80.100 nacionais e americanos para uma pressão de $0,42 \mathrm{Kgf} . \mathrm{cm}^{-2}$.

unidades estudadas, ao nível de $95 \%$ de probabilidade, estão fora do intervalo de confiança.

\subsubsection{Distribuição da Vazão}

Os bicos aspersores "Veejet 80.100" apresentam uma vazão distribuída em forma de leque, com valores decrescen tes do centro para as extremidades do jato de aspersão. No si mulador-de-chuva tipo rotativo a disposição dos bicos asperso res no aparelho permite um recobrimento, obtendo-se um valor 
médio de vazão em todos os pontos sob a chuva simulada. Assim, a regularidade da distribuição do leque de aspersão e a altura de aplicação da chuva simulada determinam variações no recobrimento das yazões dos bicos aspersores e consequentemen te, variações na uniformidade da distribuição da chuva simu1 ada

Na Figura 5, observa-se que os bicos aspersores nacionais apresentam uma forma de distribuição da vazão mais simétrica do que os bicos americanos, para a pressão de $0,42 \mathrm{Kgf} . \mathrm{cm}^{-2}$. Contudo, trabalhando com pressão mais baixa, que permita uma vazão semelhante à dos bicos americanos e pro duza a mesma intensidade de precipitação, a sua uniformidade de distribuição não deve ser a mesma.

Com os bicos nacionais, devido à maior regularidade de distribuição da vazão, dever-se-á conseguir, com a pressão de $0,42 \mathrm{Kgf} . \mathrm{cm}^{-2}$, uma distribuição mais uniforme das chuvas. Contudo, para o dimensionamento atual do aparelho, as precipitações seriam de 94 e de $188 \mathrm{~mm}^{-1}$ para 15 e 30 b $\underline{i}$ cos em funcionamento, respectivamente.

Para se ter maior controle da distribuição da chuva simulada, deve-se utilizar bicos aspersores tanto com vazões totais, como com suas distribuições de vazão uniformes. Na Tabela 1 , observa-se que apenas os bicos no 2,8 e 10 , ou seja, $30 \%$ da amostra analisada, apresentaram as características de vazão desejáveis. Os bicos No 5, 6 e 9, apesar de terem suas vazões totais dentro do intervalo de confiança, 


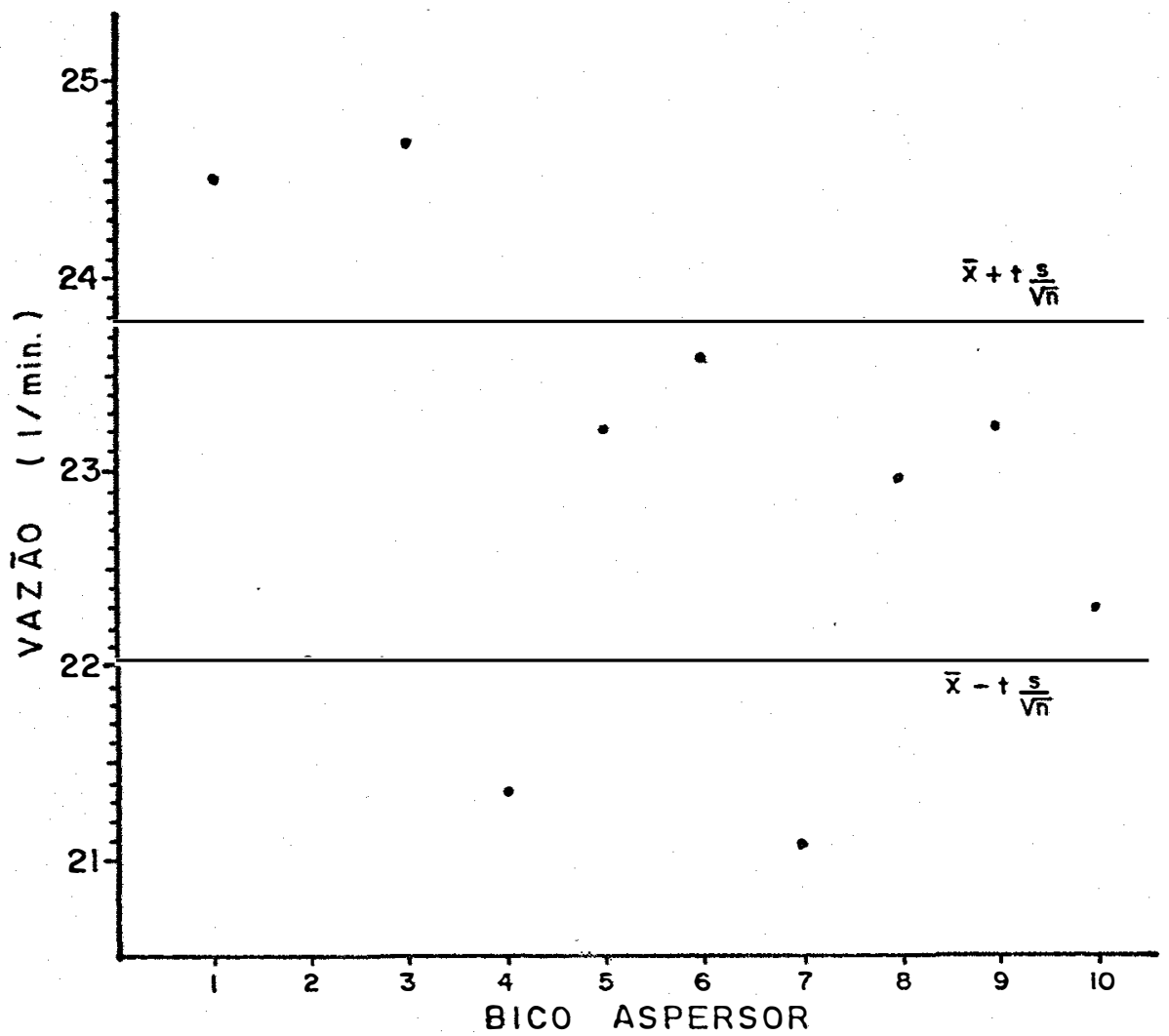

Figura 6. Gráfico de controle de qualidade dos aspersores nacionais para um intervalo de confiança com $95 \%$ de probabilidade.

apresentaram uma distribuição de vazão assimétrica. A coinci dência de seções do jato de aspersão com vazões desuniformes e com desvios do mesmo sinal, poderá produzir faixas de concentração ou de depressão na precipitação, desuniformizando a distribuição da chuva aplicada.

\subsection{Avaliação do Método Fotográfico.}

Por não se ter utilizado o mesmo equipamento e acessōrios do trabalho de LAWS (1941), modificações e adapta- 


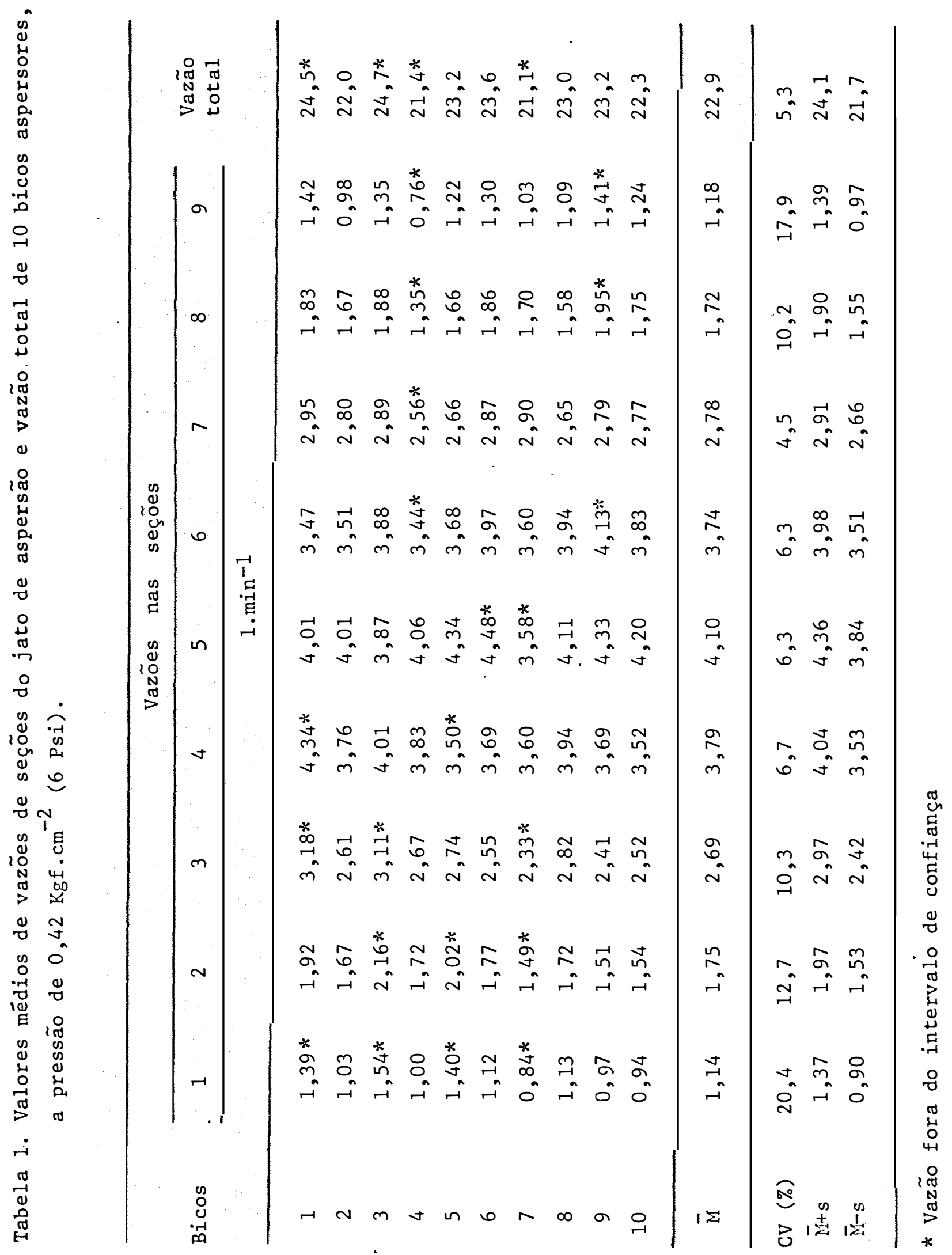


ções foram sendo introduzidas e testadas para a obtenção de uma boa qualidade de imagem (Figura 2).

Duas lâmpadas "Photoflood" No 2 de 250 W foram inicialmente utilizadas, sendo logo depois substituídas por lâmpadas de $500 \mathrm{~W}$. Diferentes ângulos de incidência dos raios luminosos foram testados, escolhendo-se, como o mais adequado, o ângulo de 450 em relação ao eixo da máquina fotogrāfica; embora LAWS (1941) tenha usado um ângulo de $30^{\circ}$. Para ca da uma dessas condições foram experimentadas diferentes aberturas de diafragma; tendo sido escolhida, invariavelmente, a abertura de 5,6. O tempo de exposição chegou, nos ensaios com gotejadores, a $12 \mathrm{~s}$, sem que tenha havido problemas de velação de filme. A ausência de reflexos, com exceção dos provenientes das gotas, possibilitou a utilização desse longo tempo de exposição. No trabalho de Laws, devido possivelmente aos reflexos da lente de colimação e das haletas colocadas en tre a máquina e o campo fotogrāfico, este tempo de exposição não foi superior a 2 s.

A qualidade dos reagentes e processo de revelação, alteração na fotossensibilidade dos filmes e precisão de focalização podem ter sido algumas das causas das diferenças de nitidez; uma vez que, mesmo para as condições de poucas go tas no campo fotográfico, durante os testes com os gotejadores, houve diferença na nitidez da imagem de filme para filme (Figura 3 a e $3 b)$. 


\subsubsection{Causas de erro nas leituras}

Além dos erros sistemáticos, distorções da ima gem pelo sistema ótico da máquina fotográfica e do projetor, variações da forma devido ao comportamento das gotas em queda, borramento da imagem pela localização no campo fotográfí co ou imprecisão da focalização do objeto são os principaisfa tores que induzem a erro nas leituras, principalmente, de diâa metro de gotas. Nas leituras verticais, para determinação da velocidade de queda, a falta de nitidez das extremidades das imagens, a imperfeição das janelas do disco obturador e as variações de rotação do motor são, por ordem decrescente, as principais fontes de erro.

LAWS (1941) utilizou, apenas, uma lente de colimação para evitar a distorção da imagem pelo sistema ótico da máquina fotográfica; entretanto, neste trabaîho, além de se procurar fazer as leituras na área central do quadro de projeção, dispensando as informações contidas nas faixas laterais com 1 arguras correspondentes a $15 \%$ das dimensões daque le quadro, foi utilizada uma tela com concavidade no sentido horizontal, para se corrigir as distorções provocadas pelo projetor de imagem sobre as leituras de diâmetro das gotas.

A precisão das leituras pôde ser considerada boa; uma vez que os dados obtidos com gotas de $3,9 \mathrm{~mm}$ parauma altura de queda de $9 \mathrm{~m}$, escolhidos ao acaso, dentre as fichas de análise, apresentaram um coeficiente de variação para as 
leituras de diâmetro de gota de $2,5 \%$ e para as leituras de ve locidade de queda, de 0,6\%. Devido as variações observadas na rotação do disco obturador, os erros nas leituras das veloci- " dades de queda podem ter chegado, no máximo, a $0,5 \%$.

4.2.2. Medidas dos diâmetros das gotas

Gotas com diâmetros superiores a aproximadamen te $3 \mathrm{~mm}$, em queda livre, sofrem deformações, devido à resis tência do ar, a medida que aumenta sua velocidade de queda. A forma elipsoidal com base achatada, observada por técnica fotográfica de alta velocidade, é alcançada a medida que as for ças, que atuam sobre a gota em queda, entram em equilíbrio. Mc DONALD (1954) cita que os fatores que devem controlar a forma das gotas grandes em queda são, principalmente, a tensão superficial, a pressão hidrostática, a pressão aerodinâmica externa e de uma forma secundária, a carga eletrostática e a cir culação interna.

Na Tabela 2, são apresentadas as variações de leitura, devido às deformações das gotas, para os diferentes tamanhos e alturas de queda, relacionando-se a distância entre os focos com o seu diâmetro esférico. Pelos dados apresen tados, observa-se que ocorrem diferentes variações de forma das gotas durante a queda. As gotas com diâmetromenor tiveram menor deformação, que permaneceu constante a partir de 2 m de altura de queda. As gotas com diâmetros intermediários 
apresentaram deformações no início da queda, que passaram a diminuir até a 5 m de altura de queda e voltaram a aumentar até os $12 \mathrm{~m}$ de queda. As gotas maiores apresentaram uma defor mação gradativa com o aumento da altura de queda. No entanto, era de se esperar que os valores da relação distância entre focos e diâmetro esférico fosse crescente até as alturas de queda necessärias para que as gotas atingissem suas velocidades terminais, ocasião em que a pressão aerodinâmica externa se estabiliza com a anulação da aceleração da gravidade.

o comportamento das gotas de tamanho intermediärio pode ser uma particularidade dessa faixa de tamanho de gota, resultante da interação das forças ainda em desequilíbrio no início da queda.

Com exceção das gotas de menor diâmetro que apresentam um valor de 0,91 para a relação citada, as demais parecem guardar uma mesma proporcionalidade de deformação, dan do valores próximos a 1, para alturas de queda superiores a 9 m. Embora se meça, na fotografia, a distância entre os focos refletidos pelas gotas e não o diâmetro maior da elipse formada pelas gotas grandes em queda, a observação visual das fotografias, de diferentes tamanhos de gota em velocidadester minais de queda, (MAGONO, 1954), parece confirmar esta propor cionalidade de deformação.

Considerando-se que as gotas com 9 a $12 \mathrm{~m}$ de altura de queda já atingiram suas velocidades terminais, assim como as gotas da chuva do simulador tipo rotativo, devido 
Tabela 2. Relação entre diâmetro medido na fotografia e diâmetro esférico, de gotas d'água, para diferentes a 1 turas de queda.

\begin{tabular}{|c|c|c|c|c|c|}
\hline \multirow{4}{*}{$\begin{array}{l}\text { Diâmetro } \\
\text { Esférico } \\
(\mathrm{mm})\end{array}$} & \multicolumn{5}{|c|}{ D. fotografia/D. esférico } \\
\hline & \multicolumn{5}{|c|}{ 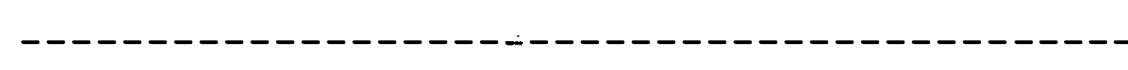 } \\
\hline & & A $1 t$ & de Queda & $(\mathrm{m})$ & \\
\hline & 1 & 2 & 5 & 9 & 12 \\
\hline 2,3 & 0,87 & 0,91 & 0,91 & 0,91 & - \\
\hline 3,1 & 1,00 & 1,00 & 0,97 & 1,00 & 1,03 \\
\hline 3,9 & 0,97 & 1,00 & 0,95 & 0,97 & 1,00 \\
\hline 5,1 & 0,94 & 0,94 & 0,98 & 1,00 & 1,04 \\
\hline
\end{tabular}

à pressão a que estão sujeitas, adotou-se o fator 1 para a conversão das leituras fotográficas em diâmetros esféricos de gotas.

Com este procedimento, pelos dados apresentados na Tabela 2, sabe-se que para as gotas de $2,3 \mathrm{~mm}$ de diâmetro subestima-se o seu tamanho em até $9 \%$ do seu diâmetro. Para go tas menores, que não sofrem deformação, considerando-se o valor da relação para as gotas $2,3 \mathrm{~mm}$ com $1 \mathrm{~m}$ de altura de queda, subestima-se o tamanho em $15 \%$, aproximadamente, de seus diâmetros. Como este erro é gradativo até um certo limite de tamanho de gota, que não sofre deformação em queda e como as gotas de menores diâmetros, apesar do seu elevado número con- 
tribuem pouco para a energia cinética total da chuva, o erro final cometido deverá ser desprezível.

Utilizando-se esse método e um fator de amplia ção da projeção de 1,5 , conseguiu-se medir gotas de, no mínimo, $0,5 \mathrm{~mm}$ de diâmetro.

\subsubsection{Medidas das Velocidades de Queda}

De um modo geral, as velocidades das gotas d'água para diferentes alturas de queda foram semelhantes às obtidas por LAWS (1941). Na Figura 7 , observa-se, contudo, que para as gotas de $2,3 \mathrm{~mm}$ de diâmetro, a partir de $2 \mathrm{~m}$ de altura de queda, as velocidades foram comparativamente mais baixas.

Uma corrente convectiva formada pelo aquecimen to do ar do salão onde foram realizados estes ensaios, foi responsável pelos decréscimos nas velocidades de queda das go tas para a altura de $12 \mathrm{~m}$. Neste tratamento, as gotas formadas pelos gotejadores colocados no ponto mais alto do salão, através de uma abertura no vidro da abóbada, sofreram a ação da massa de ar ascendente.

Possivelmente, a ação desta corrente de ar con vectiva também tenha causado a diminuição das velocidades de queda das gotas de $2,3 \mathrm{~mm}$, devido às suas pequenas massas; contudo, era de se esperar que seus efeitos também se fizessem sentir, proporcionalmente, nos demais tamanhos de gota. 


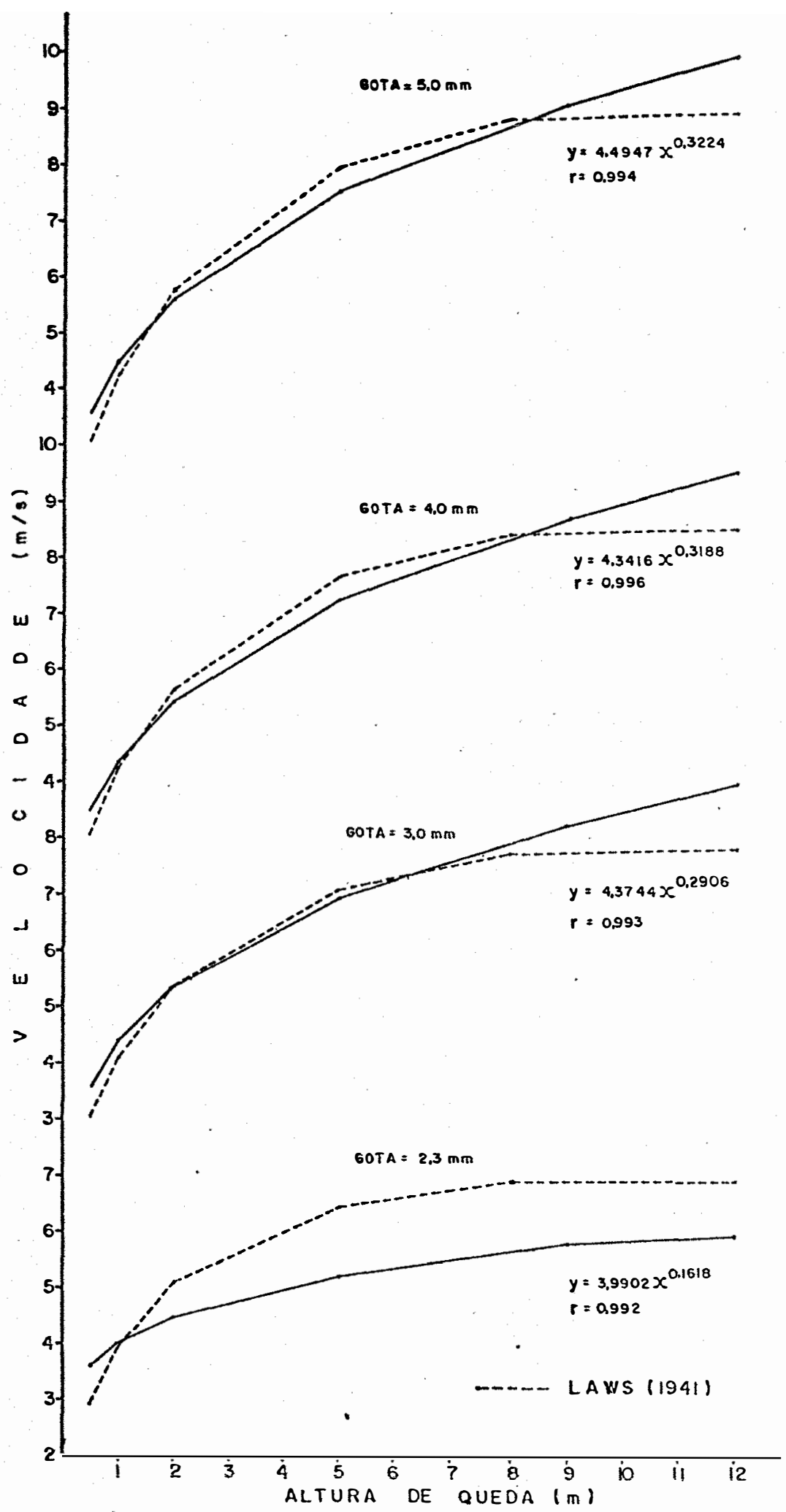

Figura 7. Velocidades de gotas d'água para diferentes alturas de queda, comparadas com as determinadas por LAWS (1941). 
As velocidades de queda estimadas para a altura de 0,5 m foram maiores do que as encontradas por LAWS (1941). Igual tendência, com exceção das gotas de $2,3 \mathrm{~mm}$ de diâmetro, ocorreu para a altura de $12 \mathrm{~m}$. A perda dos dados, pa ra esta altura de observação, ou mesmo a falta de informações para esta e outras alturas maiores de queda, limitou a defini ção da tendência das curvas que relacionam velocidade com altura de queda, que estão representadas na Figura 7 .

LAWS (1941) observou que, a partir de $12 \mathrm{~m}$ de altura de queda, todas as gotas já tinham atingido suas velocidades terminais; ou seja, passavam a ter velocidades cons tantes. Valores iguais e um pouco inferiores, de velocidade terminal de queda de gota, foram encontrados por spilHaUs (1948), GUNN \& KINZER (1949), BEST (1950) e MAGONO (1954).TaI fato leva a acreditar que as velocidades de queda calculados neste trabalho, para a altura de $12 \mathrm{~m}$, tenham sido superestimadas.

4.3. Anālise do Jato de Aspersão.

Em diferentes alturas de queda e seções do jato de aspersão de bicos Veejet 80.100 nacionais, foram tiradas fotografias, visando-se determinar o tamanho e a velocida de de queda das gotas, para se calcular as variações da ener gia cinética. 
4.3.1. Tamanho das Gotas

A composição de tamanho das gotas foi variävel, tanto ao longo do jato de aspersão, quanto com a altura de queda. Considerando-se o parâmetro $D_{50}$ (diâmetro mediano das gotas) e o parâmetro $D_{95}$ (Tabela 3 ), pode-se observar que existe uma tendência, mais evidente nas maiores alturas de queda, de ocorrerem gotas com menores diâmetros, a medida que se caminha do centro (seção 3) para a extremidade do leque de aspersão (seção 1 ). Esse comportamento pode estar relacionado com a distribuição da vazão. Na posição onde a vazão é maior, aumenta a densidade de gotas permitindo, por coalescência, a formação de gotas com maiores diâmetros.

Menores diâmetros, em posições afastadas do centro do leque de aspersão também foram encontrados por liEYER (1958); entretanto, ROTH et alii (Prelo), em dois dos bicos Veejet 80.100 de origem americana que foram estudados, encontraram um comportamento inverso. Contudo, estes autores não fizeram maiores comentärios. MEYER (1958) justificou os pequenos aumentos da vazão, nas extremidades do leque de aspersão (Figura 5), como sendo devido à ocorrência de gotas de maiores diâmetro. o que não foi observado neste trabalho, com os bicos nacionais.

Os menores diâmetros de gota ocorreram na altura de $2 \mathrm{~m}$ de queda e os maiores, na altura de $3 \mathrm{~m}$; passando a decrescer na altura de $4 \mathrm{~m}$. E possível que a turbulência da 
água na saída do bico aspersor e o impacto com o ar atmosféri co tenha promovido uma pulverização da massa de água, formando gotas pequenas (altura de $2 \mathrm{~m}$ ), que, devido às diferentes velocidades adquiridas e a grande densidade de gotas passam a se coalescerem, formando gotas maiores (alturas de $3 \mathrm{~m}$ ), e, posteriormente, pelo aumento da velocidade de queda e pelains tabilidade da forma das gotas voltam a se subdividir (altura de $4 \mathrm{~m}$ ).

Esta subdivisão das gotas é mais nítida na altura de 4 m e na extremidade do leque de aspersão, posição on de não foram observadas gotas com diâmetros superiores a 3,5 mm. Maior percurso de queda, possibilitando o aumento da velo cidade e a menor densidade de gotas, devido ao espalhamentodo jato de aspersão, evitando a coalescência, devem ser as causas da ausência das gotas grandes neste ponto de observação.

A ampla variação de distribuição de tamanho de gotas, encontrada nas diferentes alturas de queda e seções no leque de aspersão, são comparáveis à distribuição de tamanho de gotas da chuva natural, de diferentes intensidades. LAWS \& PARSONS (1943) encontraram, para a chuva natural, valores de $D_{50}$ de 1,85 e $2,85 \mathrm{~mm}$, para intensidades de 12,5 e 102,0 $m m^{-1}$, respectivamente.

A homogeneidade na distribuição de tamanho de gota nas diferentes seções do jato de aspersão (Tabela 3 ), Pạ ra alturas de $2 \mathrm{~m}$, foi que levou a se eliminar as observações das seções 4 e 5 das demais alturas de queda. "Para estas al- 
turas, observou-se que ocorre um decréscimo no tamanho das go tas, do centro para a extremidade, com uma tendêncía acentuadamente simétrica.

\subsubsection{Velocidade das Gotas}

A velocidade de queda das gotas variou pouco nas diferentes posições e com a altura de queda (Tabela 4). Considerando-se os limites de dispersão de $5 \%$ em torno da média, observa-se que as gotas de menores diâmetros $(0,75$ e $1,75 \mathrm{~mm}$ ), foram as que mais variaram de velocidade. Em seguida, vêm as gotas grandes, finalmente, as gotas de tamanho intermediärio que apresentam velocidades mais homogêneas.

As gotas com diâmetros inferiores a $2,75 \mathrm{~mm}$ apresentaram velocidades que decresceram com a altura de queda e com a distância do centro do leque de aspersão. Esse com portamento fica mais evidente, a medida que diminui o tamanho da gota considerada. As gotas grandes, embora com uma amplitude de variação menor, apresentaram um comportamento inverso; o que fica mais evidente quando não se considera os va lores anômalos ocorridos na seção 2 .

A pressão da āgua, na saída do orifício do bico aspersor, diminui do centro para as extremidades do jatode aspersão; tendo esta variação de pressão se refletido com maior nitidez nas velocidades das gotas de menores diâmetros. Mesmo assim, observa-se, na Figura 8 , que para todas as posi- 
48.

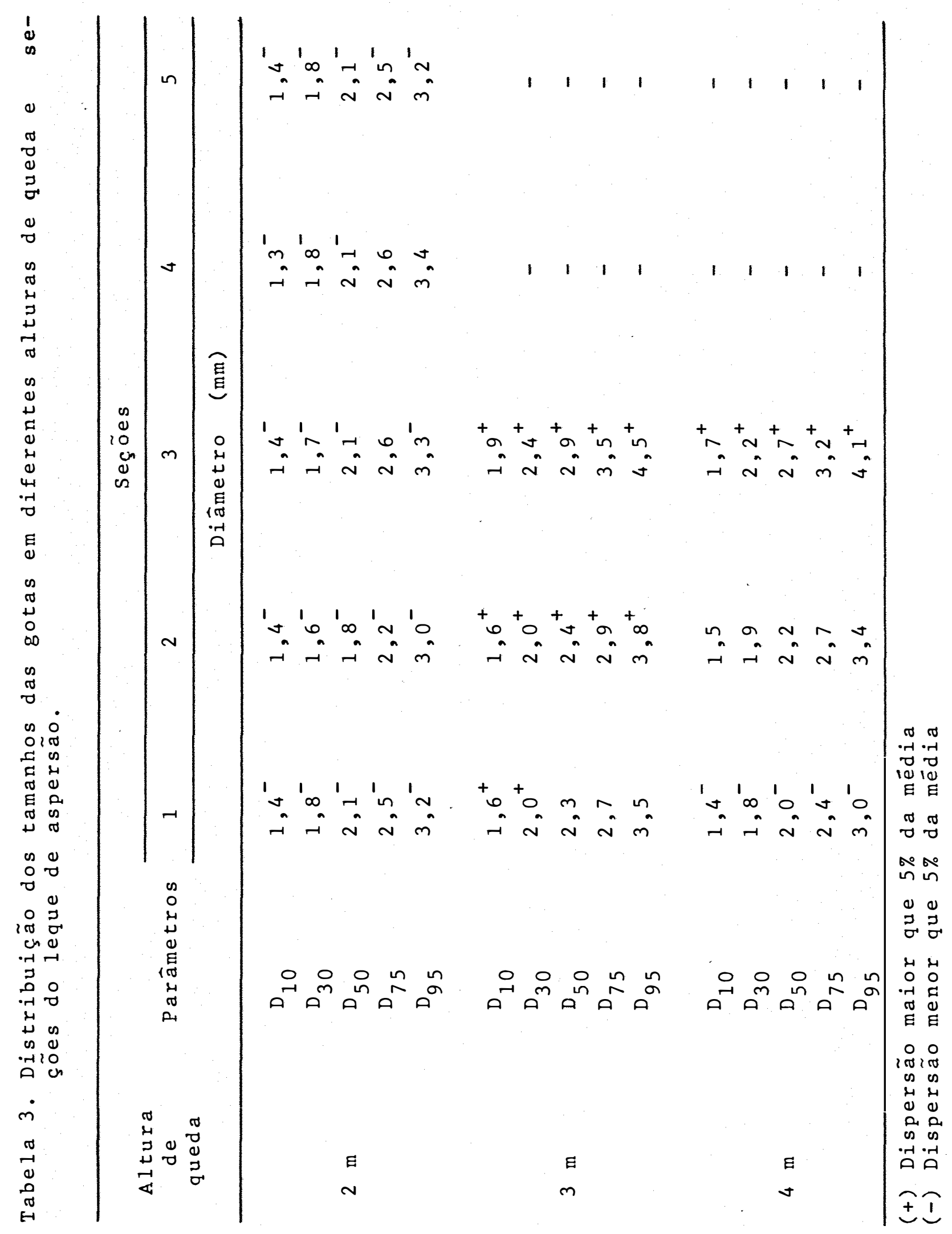


49.

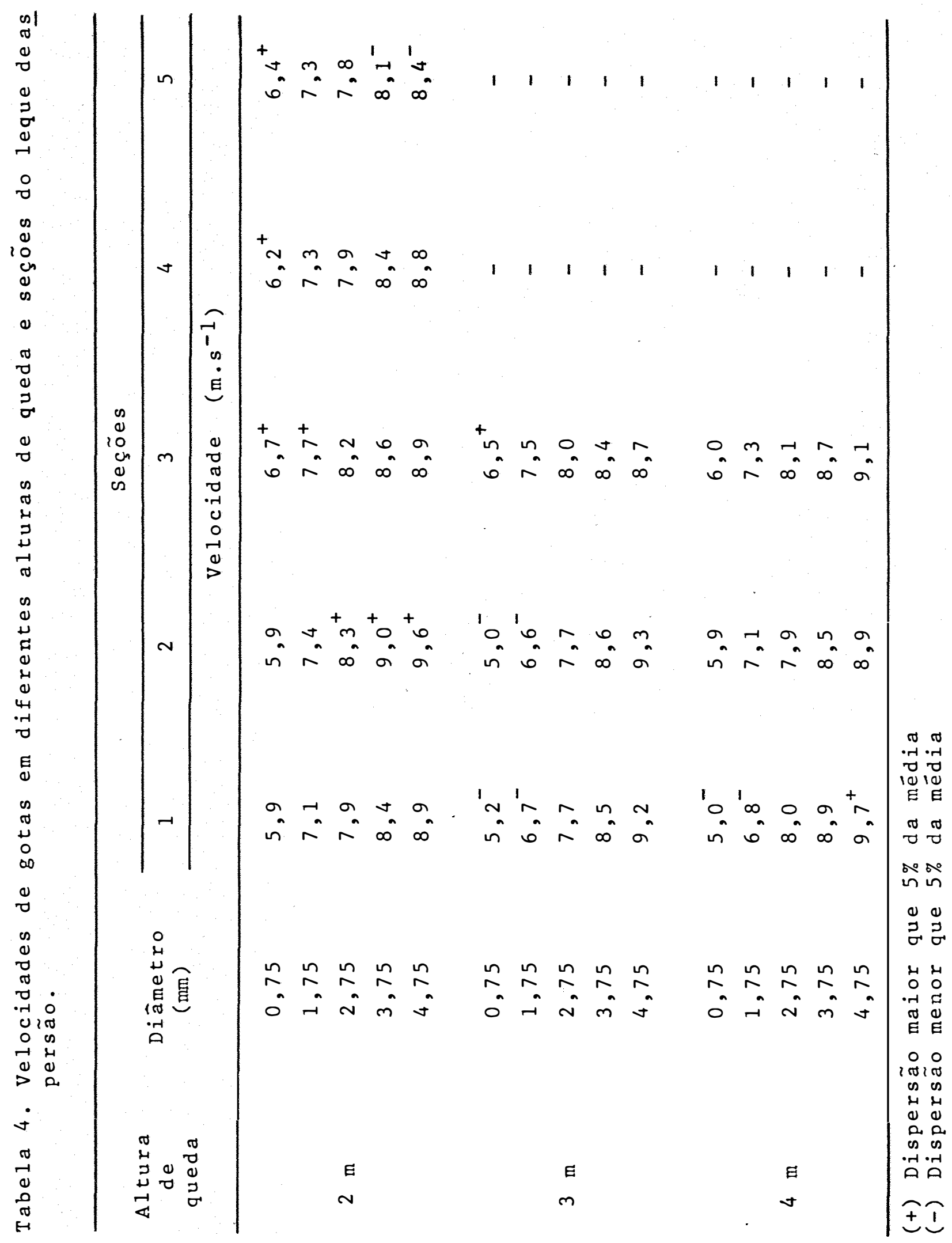




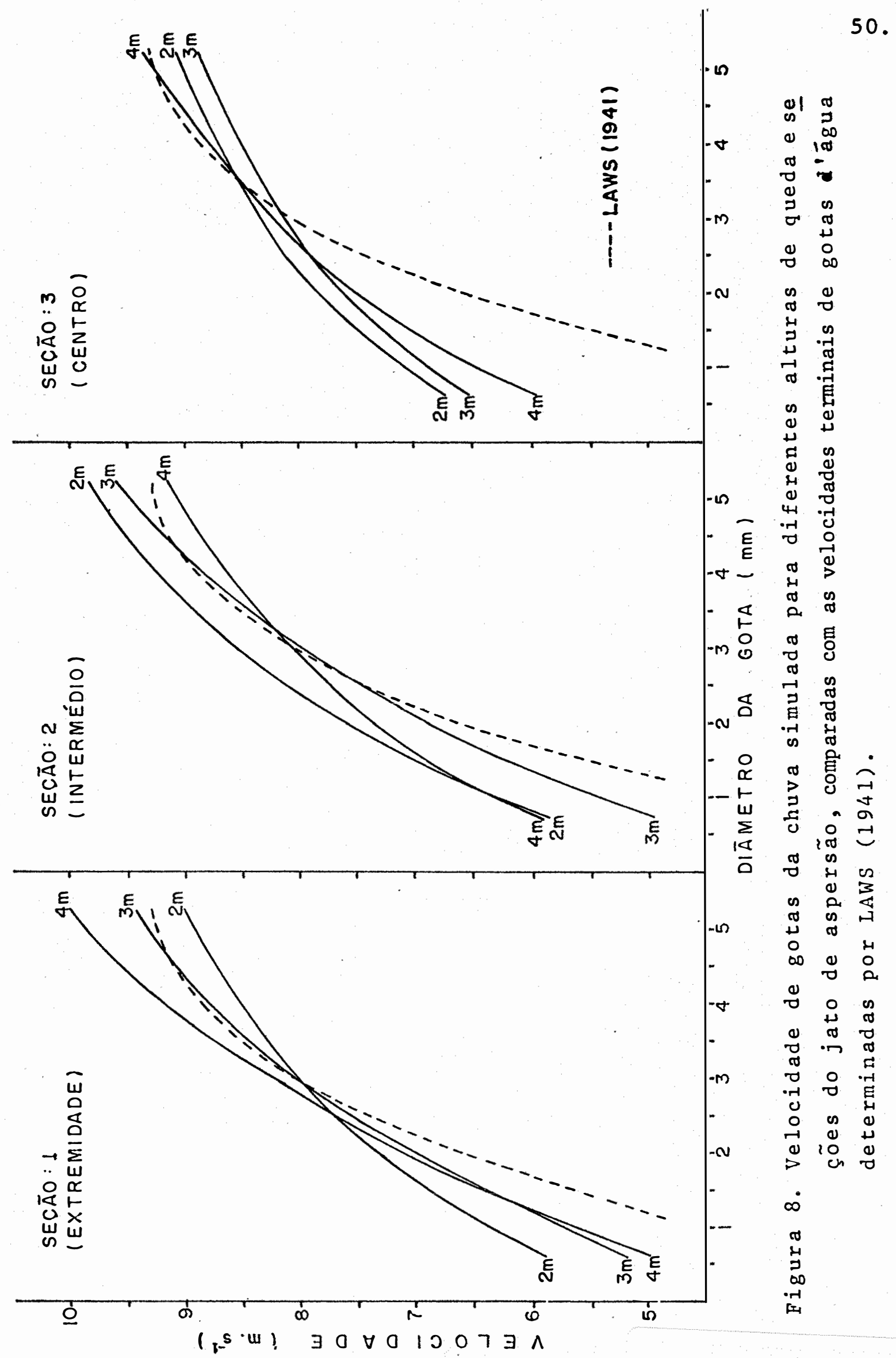


ções e alturas de queda, as magnitudes das pressões ocorridas foram suficientes para imprimir a essas gotas, velocidades su periores às suas velocidades terminais. o mesmo não ocorreu com as gotas grandes, com diâmetros superiores a $3 \mathrm{~mm}$, uma vez que, na altura de $2 \mathrm{~m}$, ainda não tiveram suas velocidades terminais alcançadas.

Inexplicavelmente, as velocidades das gotas grandes, na seção 2 , tiveram um comportamento contrário, dimi nuindo com a altura de queda.

o maior aumento da velocidade das gotas grandes, com a altura de queda, na extremidade do leque de aspersão, em comparação com as da seção central (3), pode ser devido à me nor densidade de gotas que ali ocorre; permitindo um menor nū mero de colisões com gotas pequenas de menores velocidades. A coalescência das gotas em queda deve causar um retardamento momentâneo da aceleração da velocidade, tanto pela perda de energia durante. o impacto, como pela deformação das gotas, cau sando um aumento da superfície de fricção. Porisso, as gotas grandes do centro do leque de aspersão, só atingiram suas velocidades terminais com a altura de $4 \mathrm{~m}$.

As velocidades maiores que as terminais, para as grandes gotas na seção 1 a $4 \mathrm{~m}$ de altura, podem ser devidos à permanência da instabilidade das gotas, permitindo formas de menor resistência ao ar (alongadas), ou a erros da estimativa das velocidades, uma vez que foi baixa a ocorrência dessas gotas. 
A energia cinética é função da massa e da velocidade $\left(\ddot{E c}=1 / 2 \mathrm{MV}^{2}\right)$; sendo assim, caso as velocidades de queda das gotas de mesmo diâmetro fossem as mesmas, nas diferentes alturas e seções do leque de aspersão, apenas as variações da composição do tamanho das gotas explicariam os valores da energia ci nética.

Correlacionando-se o $D_{50}$ (diâmetro mediano das gotas), com a energia cinética (Tabela 5) encontrou-se um coe ficiente de 0,72 , e com o $\mathrm{D}_{95}$, representando a ocorrência das gotas grandes, o fator de correlação foi de 0,77. Tais valores sugerem que mais de $20 \%$ das variações da energia cinética não podem ser explicadas apenas pelas variações dos tamanhos de gota.

Considerando-se os dados de tamanho de gota (Ta bela 3 ) e os de velocidade de queda (Tabela 4) pode-se observar que, para a altura de $2 \mathrm{~m}$, o maior valor da energia cinética na seção 3 foi devido às maiores velocidades das gotas pẹ quenas. Na seção 2 , os menores tamanhos de gotas foram compen sados pelas maiores velocidades das gotas grandes, equilibran do o valor da energia cinética.

Na altura de $3 \mathrm{~m}$, apesar dos maiores diâmetros de gotas, as menores velocidades das gotas pequenas, nas seções 1 e 2, reduziram a energia cinética a valores um pouco inferiores aos das respectivas seções da altura de $2 \mathrm{~m}$. Na 
seção central (3), a conjunção dos maiores diâmetros de gota, associados a valores intermediários de velocidade, produziram o maior valor de energia cinética $\left(34 \mathrm{tm} \cdot \mathrm{ha}^{-1} \cdot \mathrm{mm}^{-1}\right)$.

$$
\mathrm{Na} \text { altura de } 4 \mathrm{~m} \text {, com exceção da seção } 2 \text {, }
$$

maiores velocidades de queda das gotas grandes compensaram a diminuição das velocidades das gotas pequenas. Na seção 3 , ape sar dos menores tamanhos das gotas, em relação à altura de 3 $\mathrm{m}$, esse aumento de velocidade chegou a elevar o valor da ener gia cinética até bem próximo ao valor correspondente ao da a tura de $4 \mathrm{~m}\left(33,7 \mathrm{tm} \cdot \mathrm{ha}^{-1} \cdot \mathrm{mm}^{-1}\right)$.

Tabela 5. Energia cinética em diferentes alturas de queda e seções do leque de aspersão.

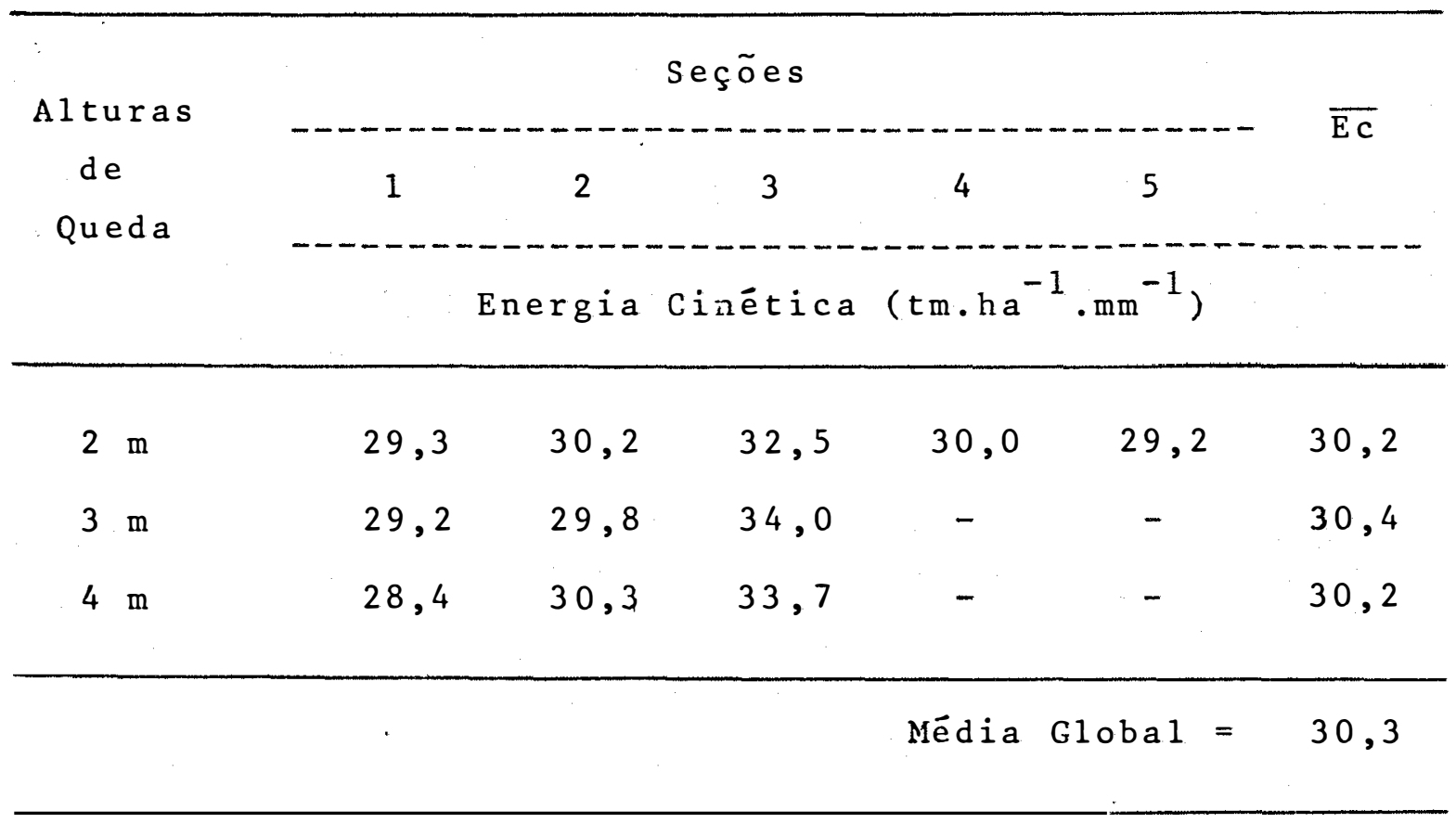


Na seção 2 para as diversas alturas de queda, apesar do comportamento anômalo, principalmente da velocidade de queda, os valores da energia cinética foram comparáveis aos das demais seções.

A tendência de decréscimos dos valores de ener gia cinética, do centro para a extremidade do leque de aspersão, também, foi observada por MEYER (1958), que encontrou vạ lores de 21,2 e $20,7 \mathrm{tm} \cdot \mathrm{ha}^{-1} \cdot \mathrm{mm}^{-1}$. ROTH et alii (Prelo), tra balhando com o mesmo tipo de bico usado por aquele autor (Veejet 80.100 americano), encontraram um valor de energia cinética de $21,3 \mathrm{tm} \cdot \mathrm{ha}^{-1} \cdot \mathrm{mm}^{-1}$, que é praticamente igual ao obtido por MEYER (1958).

o valor médio de energia cinética para as diferentes alturas de queda (Tabela 5) foram praticamente iguais, dando um valor médio global de $30,3 \mathrm{tm} \cdot \mathrm{ha}^{-1} \cdot \mathrm{mm}^{-1}$.

\subsection{Caracteristicas da Chuva Simulada}

Utilizando-se as informações sobre a distribui ção da vazão, da energia cinética e o distanciamento radial dos bicos aspersores no simulador-de-chuva tipo rotativo, foi possível compor, por sobreposição dos jatos de aspersão, histogramas das intensidades e da energia cinética da chuva simu lada para as diferentes alturas de aplicação (Figuras 9, 10 e 11). 

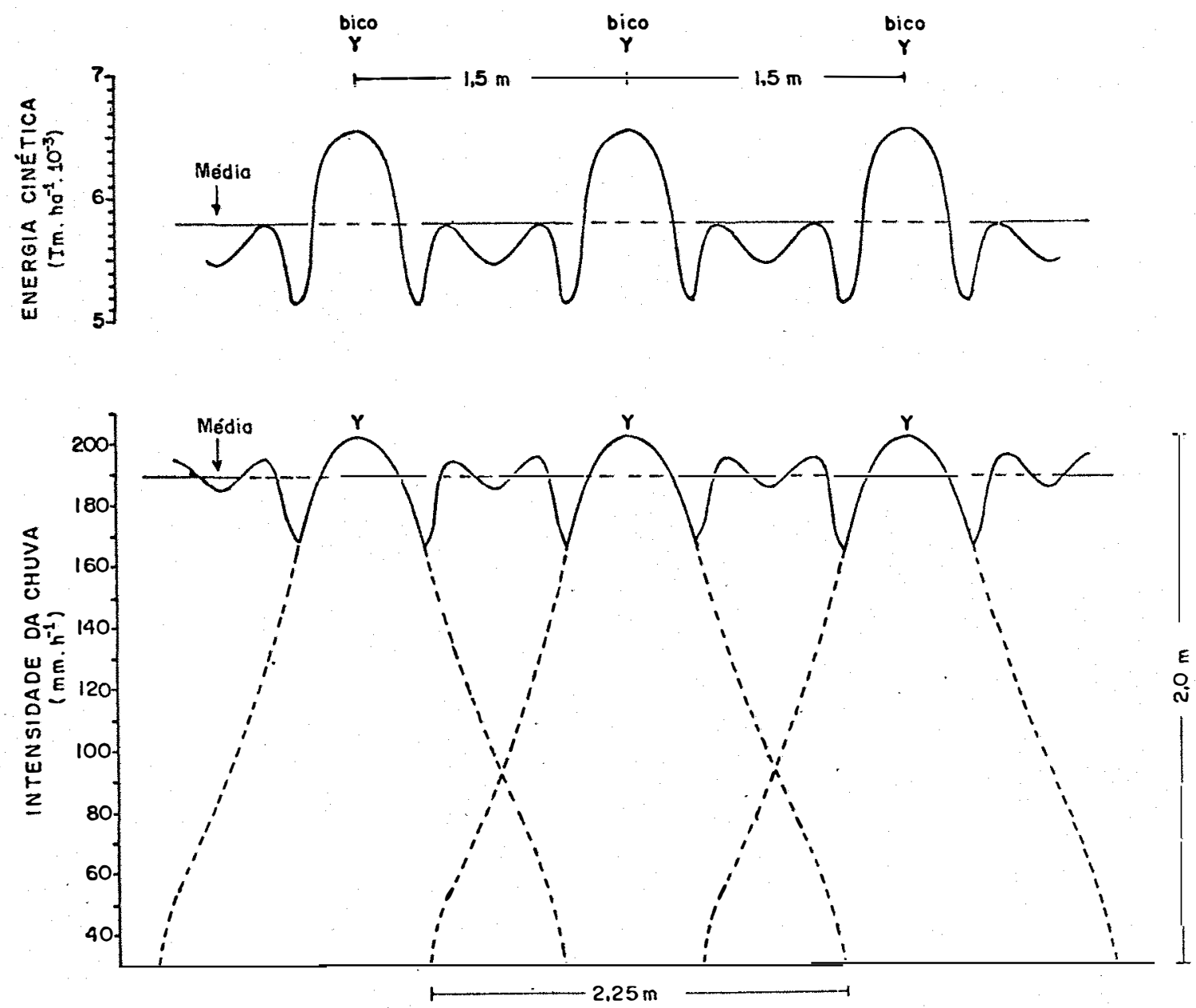

Figura 9. Distribuição das intensidades e das energias cineti cas correspondentes, para chuva com $60 \mathrm{~min}$ de duração, produzida por bicos Veejet 80.100 nacionais em simuladores-de-chuva tipo rotativo, a pressão de $0,42 \mathrm{kgf}$. $\mathrm{cm}^{-2}, 2 \mathrm{~m}$ de altura de queda e 30 bicos em funcionamento. 

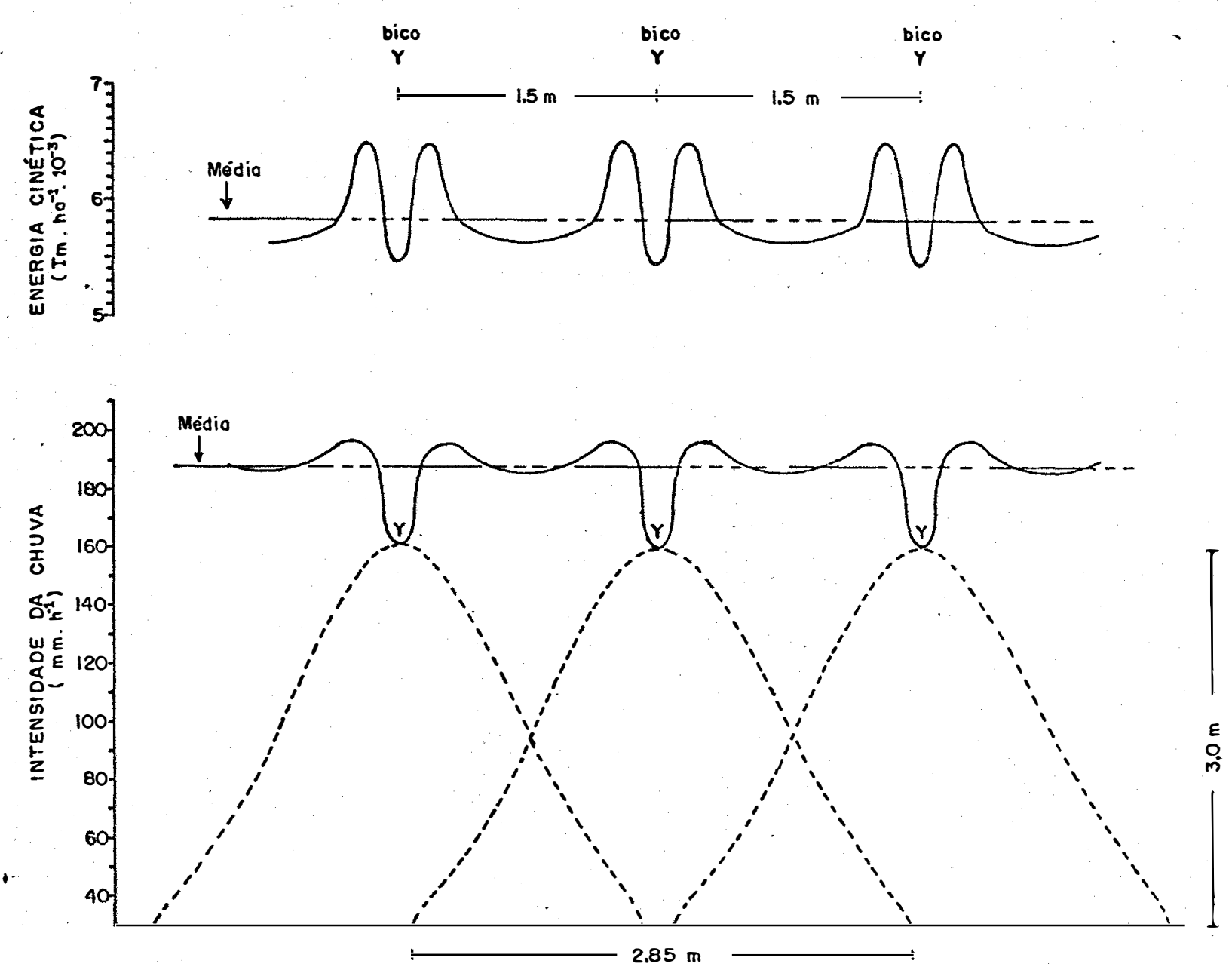

Figura 10. Distribuição das intensidades e das energias cinéticas correspondentes, para chuva com 60 min de du ração, produzida por bicos Veejet 80.100 nacionais em simulador-de-chuva tipo rotativo, a pressão de $0,42 \mathrm{kgf} . \mathrm{cm}^{-2}, 3 \mathrm{~m}$ de altura de queda e 30 bicosem funcionamento. 

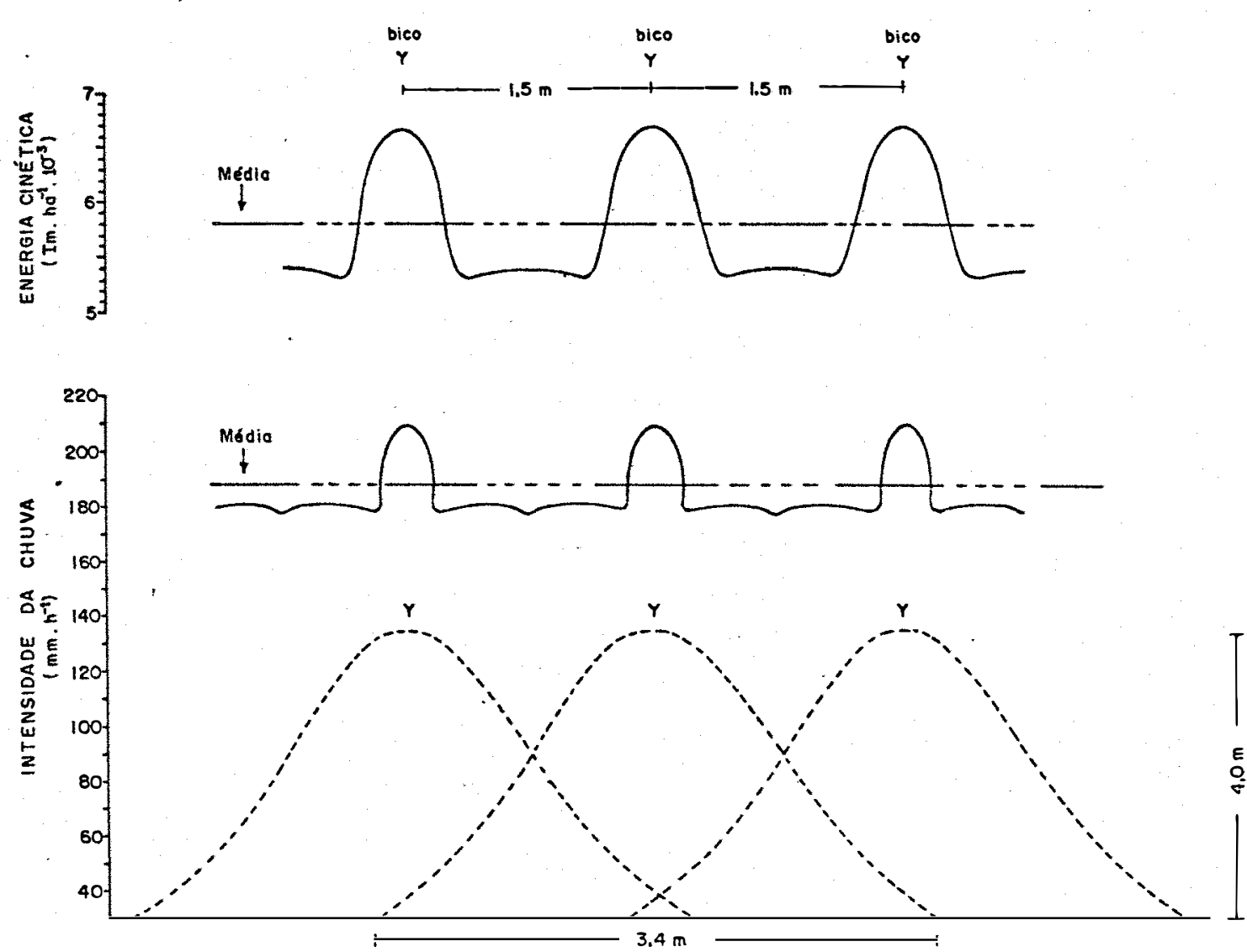

Figura 11. Distribuição das intensidades e das energias cinéticas correspondentes, para chuva com 60 min de dü ração, produzida por bicos veejet 80.100 nacionais em simuladores-de-chuva tipo rotativo, a pressãode $0,42 \mathrm{Kgf} . \mathrm{cm}^{-2}, 4 \mathrm{~m}$ de altura de queda e 30 bicos em funcionamento. 


\subsubsection{Intensidade da Chuva}

As intensidades da chuva ao longo do leque de aspersão diminuem com a altura de queda, devido ao espalhamen to das gotas; contudo, a intensidade média da chuva simulada é garantida pelo recobrimento dos aspersores vizinhos complementares.

Cada aspersor em superfície plana, cobre uma área de $7,3 \mathrm{~m}^{2}$ e sendo a vazão dos bicos estudados de 22,9 1.min ${ }^{-1}$, a intensidade média da chuva simulada será de 94 e $188 \mathrm{~mm} \cdot \mathrm{h}^{-1}$, para 15 e 30 bicos em funcionamento, respectivamente.

A medida que aumenta a altura de queda a faixa de recobrimento entre os jatos dos aspersores vão se alargando e ocorrem modificações na distribuição das intensidades da chuva, devido à adição de vazões de diferentes seções do jato de aspersão.

Na altura de 2 m (Figura 9), a curva de distri buição das intensidades tem duas depressões entre os aspersores, resultantes da frente de recobrimento das extremidades dos jatos de aspersão, que se interpenetram. Na altura de $3 \mathrm{~m}$ (Figura 10), estas depressões se unem, nos centros dos jatos de aspersão, correspondendo às faixas ainda não recobertas pe los aspersores vizinhos. A $4 \mathrm{~m}$ de altura (Figura 11), ocorre concentração da chuva, nos centros dos jatos de aspersão, devido ao início do recobrimento entre os aspersores adjacentes. 
A amplitude de variação da intensidade da chuva, nas diferentes alturas de queda estudadas, é de aproximadamente $35 \mathrm{~mm} \cdot \mathrm{h}^{-1}$. Contudo, entre as alturas de 3 e $4 \mathrm{~m}$, na faixa central do leque de aspersão, esta variação chega a 50 $\mathrm{mm} \cdot \mathrm{h}^{-1}$ e entre a altura de 2 e $3 \mathrm{~m}$, a $42 \mathrm{~mm} \cdot \mathrm{h}^{-1}$. Com o giro dos braços do aparelho, as curvas das características da chuva descrevem faixas circulares e concêntricas de variações. Em área com declive, ao longo dessas faixas, principalmente nas das äreas centrais dos bicos de aspersão, devem ocorrer variações significativas na intensidade da chuva. A avaliação da distribuição da chuva simulada, destes aparelhos, tem apre sentado coeficientes de uniformidade superiores a $85 \%$, considerados aceitáveis para trabalhos de campo, em parcelas experimentais (MONDARDO \& VIEIRA, 1975 ; CASSOL \& GUERRA, 1978 e SAUNDERS et alii, 1981a).

\subsubsection{Energia Cinética}

As variações na distribuição da energia cinéti ca foram semelhantes às das intensidades. Contudo, as amplitu des de variação foram proporcionalmente ampliadas nas seções centrais dos jatos de aspersão, com ou sem recobrimento, devi do à maior quantidade de energia por milímetro de chuva, que alí ocorre, em todas as alturas de queda.

Apesar das distribuições diferentes da energia cinētica ao longo do jato de aspersão, nas três alturas estu- 
dadas (Tabela 5), os valores médios não diferiram. Porisso, na chuva simulada ocorre, mesmo com variação da altura de queda devido à declividade, um mesmo. valor médio de energia cinética (Fig̣uras 9,10 e 11).

A energia cinética da chuva simulada, produzida por bicos aspersores Veejet $80.100\left(30,3 \mathrm{tm} \cdot \mathrm{mm} \cdot \mathrm{ha}^{-1} \cdot \mathrm{h}^{-1}\right)$ é $42,3 \%$ maior do que a da chuva produzida por bicos Vejet 80.100 americano $\left(21,3 \mathrm{tm} \cdot \mathrm{mm} \cdot \mathrm{ha}^{-1} \cdot \mathrm{h}^{-1}\right)$, para a mesma pressão de fun cionamento, $0,42 \mathrm{Kgf.cm}{ }^{-2}$.

\subsection{Erosividade da Chuva Simulada}

o potencial erosivo da chuva simulada é função das características do jato de aspersão dos bicos utilizados. os bicos nacionais, a pressão de $0,42 \mathrm{Kgf}_{\mathrm{cm}} \mathrm{cm}^{-2}$, produzem uma vazão de $22,91 . \mathrm{min}^{-1}$, e, apesar das variações de tamanho e velocidade das gotas, ao longo do jato de aspersão e com a a tura de queda, os valores de energia cinética da chuva simula da não variam ao longo do declive, sendo, aproximadamente, de $30,3 \mathrm{tm} \cdot \mathrm{ha}^{-1} \cdot \mathrm{mm}^{-1}$.

Sendo assim, o uso dos bicos nacionais em equi pamentos do tipo rotativo (SWANSON, 1965), para as condições acima citadas, produz chuvas com intensidades de 94 e 188 $\mathrm{mm} \cdot \mathrm{h}^{-1}$, para 15 e 30 bicos em funcionamento, respectivamente. 
Para um tempo de duração de $60 \mathrm{~min}$., por exemplo, o potencial erosivo das chuvas é 267,7 e $1070,9 \mathrm{tm} \cdot \mathrm{mm} \cdot \mathrm{ha} \mathrm{a}^{-1} \cdot \mathrm{h}^{-1}$, de acordo com os cálculos apresentados no subcapítulo 3.5 (página 27). Com a diminuição da pressão para que os bicos nacionais produzam precipitações de 60 e $120 \mathrm{~mm}^{-1}$, em simuladores do tipo rotativo, as caracteristicas das gotas variarão e com elas, a energia cinética. Por isso, o valor de 30,2 tm.ha $a^{-1} \cdot m^{-1}$, determinado neste trabalho, não pode ser utilizado para o cálculo do potencial erosivo dessas precipitações. MEYER (1958) encontrou um aumento da energiaci nética com a diminuição da pressão em bicos aspersores Veejet 80.100 e Veejet 8070 , nas extremidades do leque de aspersão, devido à presença de gotas grandes. Caso. isto ocorra com os bicos nacionais, a menor pressão deveria fazer com que chuvas com a mesma intensidade das produzidas pelos bicos Veejet 80100 americanos $\left(20,7 \mathrm{tm} \cdot \mathrm{ha}^{-1} \cdot \mathrm{mm}^{-1}\right.$ para $\left.0,42 \mathrm{Kgf}^{-1} \mathrm{~cm}^{-2}\right)$, contenham mais energia por mm de chuva, e consequentemente, maior potencial erosivo.

Em todo caso, é necessärio conhecer tanto as caracteristicas da chuva simulada como as das que se queira simular, para se estabelecer um fator de correção dos valores da energia cinética. A chuva simulada combicos nacionais, a pressão de $0,42 \mathrm{Kgf} . \mathrm{cm}^{-2}$, tem energia cinética de 30,3 $\mathrm{tm} \cdot \mathrm{ha}^{-1} \cdot \mathrm{mm}^{-1}$, um pouco maior do que a das chuvas de Washington (USA), estimada por WISCHMEIER e SMITH (1958), para uma inten sidade de $94 \mathrm{~mm} \cdot \mathrm{h}^{-1}$, que é de $29,7 \mathrm{tm} \cdot \mathrm{ha} \mathrm{a}^{-1} \cdot \mathrm{mm}^{-1}$. 


\section{CONCLUSÕES}

Da discussão dos resultados obtidos foram tira das as conclusões apresentadas a seguir.

5.1. Conclusões parciais

A. Método fotogrä́tico.

0 método fotográfico permite, com boa precisão, determinar-seo tamanho e a velocidade de queda das gotas.
B. Vazão dos bicos aspersores
Os bicos aspersores nacionais têm vazões varia veis e em média, $8,11 \cdot \mathrm{min}^{-1}$ a mais do que as dos bicos asper sores americanos.

Apenas $30 \%$ dos bicos aspersores nacionaj.s têm vazão regular e distribuição simëtrica.

A distribuição mēdia da vazão dos bicos asper- 
sores nacionais é mais simética do que a dos bicos americanos; contudo, a uma pressão mais baixa que permita simular as intensidades-padrão de chuva, a sua uniformidade de distribui ção não deve ser a mesma.

\section{Características da chuva do jato de aspers ão \\ Os menores tamanhos de gotas ocorrem para a a 1} tura de $2 \mathrm{~m}$ de queda e os maiores, para $3 \mathrm{~m}$; sendo que para todas as alturas estudadas, os diâmetros das gotas diminuem do centro para as extremidades do leque de aspersão, com diâmetros medianos de gota $\left(D_{50}\right)$ que variaram de 1,8 a $2,9 \mathrm{~mm}$.

As gotas pequenas, cujas velocidades diminuem com a altura de queda e a medida que se distanciam do centro do leque de aspersão, atingem velocidades superiores às suas velocidades terminais. As gotas grandes têm comportamento in verso, só atingindo as suas, velocidades terminais a partir de 3 m de altura de queda, salvo na seção central do leque de a persão, em que a velocidade terminal é atingida a partir de $4 \mathrm{~m}$ de altura de queda.

Em todas as alturas de queda, a energia cinética diminui do centro $\left(34,0 \mathrm{tm} \cdot \mathrm{ha}^{-1} \cdot \mathrm{mm}^{-1}\right)$ para as extremida des do jato de aspersão $\left(28,4 \mathrm{tm} \cdot \mathrm{ha}^{-1} \cdot \mathrm{mm}^{-1}\right)$; entretanto, o seu valor mëdio $\left(30,3 \mathrm{tm} \cdot \mathrm{ha}^{-1} \cdot \mathrm{mm}^{-1}\right)$ permanece constante. 
D. Características. da chuva simulada

A intensidade da chuva não é homogênea e se a 1 tera devido à variação no recobrimento dos bicos aspersores, que ocorre com a altura de queda; contudo, o seu valor médio não varia, sendo de 94 e de $188 \mathrm{~mm} \cdot \mathrm{h}^{-1}$, para 15 e $30 \mathrm{bicos}$ as persores em funcionamento, respectivamente.

A energia cinética sofre variações com a inten sidade da chuva e com as características das gotas, embora mantenha um valor médio constante $\left(30,3 \mathrm{tm} \cdot \mathrm{ha}^{-1} \cdot \mathrm{mm}^{-1}\right)$, independentemente da altura de aplicação da chuva.

A erosividade das chuvas de $60 \mathrm{~min}$ de duração é de 277,7 e de 1070,9 tm.mm.ha ${ }^{-1} \cdot \mathrm{h}^{-1}$, respectivamente, para 15 e 30 bicos em funcionamento.

5.2. Conclusão geral

A energia cinética da chuva, produzida por simuladores do tipo rotativo com bicos aspersores Veejet 80.100 nacionais, apresenta variações em sua distribuição que se modificam com a altura de queda, devido a diferenças nos tamanhos das gotas, velocidades de queda e intensidades; entretanto, o valor médio da energia cinética não varia com a altu ra de aplicação da chuva. 


\section{BIBLIOGRAFIA CITADA}

BARNETT, A.P. \& A.E. DOOLEY, 1972. Erosion potential of natural and simulated rainfall compared. Trans. Amer. Soc. of Agric. Engr. St. Joseph, 15(6): 1112-1114.

BEST, A.C., 1950. The size distribution of raindrops. Quarte 1y J. Roya1 Meteor. Soc., London 76: 302-11.

CANNON, T.W., 1970. High-speed photography or airborne atmospheric particles. Jour. of Applied Meteor. Boston, $\underline{9}(1): 104-108$.

CARTER, C.E.; GREER J.D.; BRAND, H.J. \& J.M. FLOYD, 1974 . Raindrop characteristics in south central United States. Trans. of ASAE, St. Joseph, 17(6): 1033-1037.

CASSOL, E.A. \& M. GUERRA, 1978. Calibração do primeiro apare1ho simulador de chuvas de braços rotativos do estado do Rio Grande do Sul. Anais do IIO Encontro Nacional de Pesquisa sobre Conservação do Solo. EMBRAPA, Passo Fundo, RS. 29-39. 
CHAVES, I.B., 1977. Erosividade das chuvas na micro-região ho mogênea brasileira no 98 (Estado da Paraíba). Piracicaba, ESALQ/USP, 99 p. (Tese de Hestrado).

CHAVES, I.B. \& E.J. DINIZ, 1980. Erosividade de chuvas no estado da Paraíba. IIIO Encontro Nacional de Pesquisa em Con servação do Solo. Recife, PE.

EMBRAPA/IAPAR, 1975. Encontro nacional sobre pesquisa de exosão com simuladores de chuva (IO) Anais. IAPAR, Londrina, PR. $125 \mathrm{p}$.

FOSTER, G.R.; EPPERT, F.P. \& L.D. MEYER, 1979.A programmable rainfall simulator for field plots. In: proceedings of the rainfall simulator workshop. Tucson, Arizona, 45-59 p.

GREEN, R.L., 1952. A photographic technique for measuring the sizes and velocites of water drops from irrigation sprinklers. Agric. Engineering, St. Joseph, 33: 563-568.

GUNN, R. \& G.D. KINZER, 1949. Terminal velocity of water droplets in stagnant air. Jour. Meteor. Boston, 6(4): 243 -248 .

HUDSON, N.W., 1964. A review of methods of measuring rainfal1 characteristics relader to soil erosion. Research Bulletin no 1 , Salisbury, Southern Rhodesia. 19 p.

HUDSON, N., 1971. Soil conservation. Ithaca, Cornell Uniservi ty Press. 320 p.

KINNELL, P.I.A., 1973. The problem of assessing the erosive power of rainfall from meteorological observations. Soil Sci. Soc. Amer. Proc., Madison, 37(4): 617-621. 
LAWS, J.C., 1941. Measurements of the fall-velocity of water drops and raindrops. Trans. Amer. Geoph. Union. Washington, 22: $709-721$.

LAWS, J.C. \& D.A. PARSONS, 1943. The relation of raindropsize to intensity. Trans. Amer. Geoph. Union. Washington, 24: 452-459.

LEPRUN, J.C., 1981. A erosão, a conservação e o manejo do so1 o no Nordeste brasileiro; balanço, diagnóstico e novas $1 \underline{i}$ nhas de pesquisa. Recife, SUDENE-DRN, 106 p. (Série: Brasil. SUDENE, Recursos de solos, 15).

LEPRUN, J.C., 1984. Primeira avaliação do diâmetro de gotas de chuva no Nordeste. Resumo do vọ Encontro Nacional de Pesquisa em Conservação do Solo, Porto Alegre, RS, p. 73 .

MAGONO, C., 1954. Shorter contribution on the shape of water drops falling in stagnent air. Journal of Meteorology. Lancaster, $11(2): 77-9$.

MASON, B.J. \& J.B. ANDREWS, 1960. Drop-size" distributions form various types of rain. Quart. Journ. Roy. Meteor. Soc. London, 86: 346-353.

MCDONALD, J.E., 1954. The shape and aerodynamics of 1 arge raindrops. Journal of Meteorology. Lancaster, 11(4): 478 94.

McGREGOR, K.C. \& C.K. MUTCHLER, 1976. Status of the R factor in northern Mississippi. In: Soil Erosion - Prediction and control. Soil. Cons. Soc. Am., Ankeny, Iowa, 135-142. 
MEYER, L.D., 1958. An investigation of methods for simulating rainfall on standard runoff plots and a study of the drop size, velocity and Kinetic energy of selecter spray nozzles. USDA-ARS Special Report 으 81,43 p.

MEYER, L.D . \& D.L. McCUNE, 1958. Rainfall simulator for runoff plot. Trans. Amer. Soc. of Agric. Engr. 39(10): 644-648.

MEYER, L.D. \& W.C. HARMON, 1979. Multiple-intensity rainfall simulator for erosion research on row sideslopes. Transactions of ASAE. St. Joseph, 22(1): 100-3.

MONDARDO, A. \& M.J. VIEIRA, 1975. Apresentação de programas de pesquisa em conservação do solo no Brasil. Anais do Io Encontro Nacional sobre Pesquisa de erosão com simuladores. de chuva. IAPAR, Londrina, PR, 3-25.

ROTH, C.H.; J.C. HENKLAIN \& G.S. FARIAS, (Prelo). Avaliação preliminar do tamanho de gotas de chuva natural e simulada para o Norte do Paraná. Rev. Bras. Cien. Solo, Campinas, SP. $17 \mathrm{p}$.

SAUNDERS, L.C.V.; J.R.C. SILVA; E.G.S. MOREIRA; A.L. RODRIGUES; F.O.B. HOTA; S.S. FIGUEIREDO; J.R.P. SOUSA; M.R.P. TÁVORA \& \& J.B. PAIVA, $1981 \mathrm{a}$. Comparação de resultados da calibração de dois simuladores-de-chuva de braços rotativos para pesquisa conservacionista no Ceará. In: IIIo En contro Nacional de Pesq. sobre Cons. do Solo. UFRPE, Reci$\mathrm{fe}, \mathrm{PE}, 75-86 \mathrm{p}$.

SAUNDERS, L.C:V.; F.O.R. MOTA; A.L. RODRIGUES; E.G.S. MOREIRA; J.B. PAI VA \& J.R.C. SILVA, 1981b. Coeficiente de descarga dos aspersores "Veejet $80.100 "$ de simuladores-de-chuva de braços rotativos. In: IIIO Encontro Nacional de Pesq. sobre Cons. do Solo. UFRPE, Reci fe, $P E, 87-98 \mathrm{p}$. 
SPILHAUS, A.F., 1948. Raindrop size, shape and falling speed. Journal of Meteorology. Lancaster, $\underline{5}(2): 108-110$.

SWANSON, N.P., 1965. Rotating-boom rainfall simulator. Trans: ASAE. St. Joseph $8(1): 71-72$.

WISCHMEIER, W.H . \& D.D. SMITH, 1958. Rainfall energy and its relationship to soil loss. Trans. Amer. Geoph. Union. Washington 39(2): 285-291.

YOUNG, R.A. \& R.E. BURWELL, 1972. Prediction of runnoff and erosion from natural rainfall using a rainfall simulator. Soil Sci. Soc. Am. Proc. Madison 36(5): 827-830. 
70.

ANEXO

SUGESTÕES PARA PESQUISA

A partir dos resultados deste trabalho, pode se sugerir as seguintes pesquisas:

a) os bicos nacionais devem ser analisados sob uma pressão que possibilite produzir chuvas com intensidadespadrão, visando-se determinar as suas características;

b) os bicos nacionais, por apresentarem vazão grande e bem distribuída, podem servir para o desenvolvimento de simuladores mais adaptados às condições das chuvas tropicais, normalmente com alta intensidade e alta energia cinétic a ;

c) os efeitos da variação das características da chuva simulada devem ser avaliados para diferentes alturas de queda, visando-se quantificar suas influências nas perdas de solo e àgua;

d) deve-se estudar o tamanho ideal de amostra, que possibilite se conhecer o espectro das gotas de chuvas;

e) deve-se avaliar a precisão dos diferentes mé todos de análise das características de chuvas. 